\title{
Genç Sporcularda Diurnal Değişkenliğin Yüksek Şiddetli Egzersiz Sonrası Toparlanmaya Etkisi
}

\author{
The Effect of Diurnal Variation on Young Athletes Recovering from \\ High-Intensity Exercises
}

\begin{abstract}
M. Ali ÖZÇELİK* Alpay GÜVENÇ**

Öz: Bu çalışmanın amacı, genç sporcularda yüksek şiddetli yüklenme ve sonrasındaki toparlanma yanıtlarında diurnal değişkenlik etkisinin incelenmesidir. Araştırmaya en az 2 yıl antrenman geçmişi olan 27 erkek sporcu katılmıştır. Sporcuların anaerobik performansları her bir test ayrı bir günde olmak üzere günün beş farklı zaman diliminde $\left(08::^{00}-09::^{00} ; 10:^{00}-11:^{00} ; 12:^{00}-13::^{00} ; 15:^{00}-16:^{00} ; 17:^{00}-18:^{00}\right)$ Wingate Anaerobik Güç Testi (WAnT) ile değerlendirilmiştir. Aynı zamanda, dinlenik, WAnT sırasında ve sonrasındaki toparlanmanın 21 dakikası boyunca olmak üzere kalp atım hızı $(\mathrm{KAH})$, oksijen tüketimi $\left(\mathrm{VO}_{2}\right)$, vücut sıcaklığı ve ortalama kan basıncı yanıtları belirlenmiştir. Tekrarlı ölçümlerde tek yönlü varyans analizi sonucunda, WAnT'de kaydedilen KAH ve vücut sıcaklığı yanıtlarının akşamüstü saatlerine göre sabah saatlerinde anlamlı ölçüde daha düşük gerçekleştiği belirlenmiştir $(p<0.05)$. Günün beş farklı zamanında kaydedilen dinlenik değerler, anaerobik performans düzeyleri ve birçok toparlanma değerlerine ilişkin zamanlar arasında anlamlı ölçüde faklılık yoktur ( $p>0.05)$. Ancak bunlara ilişkin ortalama değerler dikkate alındığında, kaydedilen anaerobik performans düzeyi, dinlenik ve toparlanmaya ilişkin KAH, $\mathrm{VO}_{2}$ ve vücut sıcaklığı yanıtlarının akşamüstü saatlere göre sabah saatlerinde daha düşük değerlere sahip olduğu gözlenmiştir. Bununla birlikte KAH toparlanma oranı da akşamüstü saatlere göre sabah saatlerinde daha fazladır. Sonuç olarak, yüksek şiddetli egzersiz performansı akşamüstü daha yüksek olma eğilimi gösterirken, toparlanma yanıtları sabah saatlerinde daha fazla olma eğilimindedir.
\end{abstract}

Anahtar sözcükler: Toparlanma, Diurnal Değişkenlik, Anaerobik Performans, Egzersiz

Abstract: This study examines the effect of diurnal variation on the recovery of young athletes following high-intensity exercise. Twenty-seven male athletes with at least 2 years of training experience participated in this study. Anaerobic performance was assessed at five different times of day $\left(08:^{00}\right.$ $09::^{00} ; 10:^{00}-11:^{00} ; 12:^{00}-13:^{00} ; 15:^{00}-16:^{00} ; 17:^{00}-18:^{00}$ ) using the Wingate Test (WAnT) with each test performed on a different day. The heart rate (HR), oxygen consumption $\left(\mathrm{VO}_{2}\right)$, body temperatures and mean arterial blood pressure values were also recorded while at rest, during WAnT and during the 21minutes of recovery period. Repeated ANOVA test results showed the HR and body temperature responses to WAnT were significantly lower in the morning than in the early-evening $(\mathrm{p}<0.05)$. Both anaerobic performance, the resting, and most of the recovery values did not vary significantly between different times of day $(p>0.05)$. However, when mean values were considered, anaerobic performance, the resting and recovery values of $\mathrm{HR}, \mathrm{VO}_{2}$ and body temperature were slightly lower in the morning than in the early evening. Moreover, the recovery rates of HR were slightly higher in the morning. In conclusion, it was shown that high-intensity exercise performance tended to be higher in the early evening hours, but that the rate of recovery from high-intensity exercise tended to be higher in the morning hours.

Keywords: Recovery, Diurnal Variation, Anaerobic Performance, Exercise

\footnotetext{
* Öğr. Gör., Akdeniz Üniversitesi, Spor Bilimleri Fakültesi, Rekreasyon Böl., Antalya. aliozcelik@akdeniz.edu.tr

** Doç. Dr., Akdeniz Üniversitesi, Spor Bilimleri Fakültesi, Antenörlük Eğitimi Böl., Antalya. guvenc@akdeniz.edu.tr $\mathrm{Bu}$ çalışma Akdeniz Üniversitesi, Sağlık Bilimleri Enstitüsü, Hareket ve Antrenman Bilimleri Anabilim Dalında, Doç. Dr. Alpay GÜVENÇ danışmanlığında bitirilmiş olan Mehmet Ali ÖZÇELIK'in Yüksek Lisans Tezi’nden üretilmiştir.
} 
Bütün canlı varlıklar gibi insan organizması da zamanın değişimiyle birlikte oluşan çevresel farkl1lıklara göre, değişkenlik içerisindedir (Reilly, Atkinson \& Waterhouse 1997; Reilly 2009; Rosa 2016). Belirli bir zaman diliminde ve belli aralıklarla ardışık olarak tekrar eden döngüsel değişkenliklere biyolojik ritim denir. Biyolojik ritimlerin etkilerini ve biyolojik ritimleri yöneten etkenleri araştıran bilim dalı ise kronobiyoloji'dir. Kronobiyoloji'de bir güneş günüyle ilişkili olarak oluşan karanlık aydınlık döngüsüne ve buna ilişkin değişkenliklere sirkadiyen ritim denilmektedir (Atkinson \& Reilly 1996; Reilly, Atkinson \& Waterhouse 1997). İnsan organizmasının bütün fonksiyonlarının ayarlanmasında ritmik değişkenlikler önemlidir ve bunlardan en bilinen ve etkin olanı 24 saat süren, düzenli bir biyolojik ritim olan sirkadiyen ritimdir (Atkinson \& Reilly 1996; Reilly 2009; Rosa 2016). Vücut fonksiyonlarını kontrol eden ve ayarlayan endokrin sistem günlük bir salınım sergilemekte ve fizyolojik, psikolojik ve bilişsel fonksiyonlarda sirkadiyen ritim nedeniyle gün içerisinde değişkenlikler gözlenmektedir (Atkinson \& Reilly 1996; Reilly, Atkinson \& Waterhouse 1997; Rosa 2016). Başka bir deyişle, sirkadiyen ritme bağlı olarak tüm vücut fonksiyonları da gün içi ya da diurnal değişkenlikler ve salınımlar içerisindedir (Atkinson \& Reilly 1996; Reilly, Atkinson \& Waterhouse 1997; Rosa 2016). Bu bağlamda, diurnal ya da gün içi salınımların sportif performans düzeyi üzerinde de etkili olduğunu ve birçok fiziksel performans bileşeninin gün içerisinde değişkenlik sergilediğini gösteren çok sayıda bilimsel araştırma bulunmaktadır (Atkinson \& Reilly 1996; Reilly, Atkinson \& Waterhouse 1997; Reilly 2009; Rossi 2015; Thun 2015; Cristancho 2016; Ghattassi 2016; Rosa 2016).

Sportif performansta biyolojik ritimlerin önemi; antrenmanların planlanması, dönemlenmesi ve organize edilmesinde, müsabakalarının programlanmasında ve müsabaka amaçlı saat dilimi farklılıklarının olduğu meridyenler arası uzun yolculuklarda adaptasyonun sağlanması ile ilgili olarak ele alınmış ve araştırılmıştır (Atkinson \& Reilly 1996; Reilly, Atkinson \& Waterhouse 1997; Reilly 2009; Hatfield, Nicoll \& Kraemer 2016; Rosa 2016). Birçok sportif performans bileşeninin gün içerisinde zirve yaptığ dönemler, genellikle vücut sıcaklığına ilişkin günlük ritimle ve vücut sıcaklığının en yüksek olduğu saatlerle örtüşmektedir (Atkinson \& Reilly 1996; Reilly, Atkinson \& Waterhouse 1997; Reilly 2009; Rosa 2016). Diğer taraftan fiziksel performansın zirve yaptı̆̆ zaman aralıkları da bireyler arasındaki kronotip farklılıklarına göre değişkenlik sergileyebilmektedir (Rossi 2015; Rosa 2016). İlgili literatürde, spor müsabakalarında kırılan rekorlarının genellikle vücut sıcaklığının da yüksek olduğu akşamüstü saatlerinde gerçekleştiği bildirilmektedir (Callard 2001; Rosa 2016). Bununla birlikte öğleden sonra ve akşamüstü saatlerde esnekliğin, kas kuvvetinin ve patlayıcı kuvvetin en yüksek değerlere ulaştığ 1 yönünde araştırma bulguları mevcuttur (Reilly, Atkinson \& Waterhouse 1997; Callard 2001; Reilly 2009; Rosa 2016). Buna benzer pek çok bulgu, performans üzerindeki zamana bağl1 değişkenliklerin vücut sıcaklığındaki günlük ritimle eşzamanlı olarak seyrettiğini göstermektedir (Reilly, Atkinson \& Waterhouse 1997; Rosa 2016). Bütün bunlar sirkadiyen ritmin sportif performansa etkisini ortaya koymakta ve spor bilimciler, antrenörler ve sporcuların insanın biyolojik yapısı ve çevresel etkenlerden kaynaklanan bu ritmik değişkenlikleri dikkate alması gerektiğini göstermektedir.

Diğer taraftan antrenmandan beklenen etki; yüklenme, yenilenme ve kronik uyum ya da adaptasyonun bir ürünüdür. Buradan da anlaşılacağı üzere doğru yüklenme ve yüklenmeye verilen yanıtlar kadar, buna uygun düşen dinlenme ve yenilenme süreçleri de önemlidir. Yüklenme sonrası ve müsabaka sonrası toparlanma dönemi, bir sonraki yüklenmenin ne zaman yapılacağını belirlediği kadar, bir sonraki yüklenmenin kalite özelliğini de belirlemektedir. Bu durum toparlanma sürecinin hem sporcular için hem de antrenmanı planlayanlar açısından ne kadar önemli olduğunu göstermektedir. Ancak literatürde yer alan biyolojik ritimlerle, özellikle 
de sirkadiyen ritimle ilgili olarak, diurnal değişkenliklerin sportif performans bileşenleri üzerindeki etkilerini inceleyen çok sayıdaki çalışmada, farklı yüklenme yöntemlerine verilen yanıtlardaki değişimler ele alınmıştır. Diğer bir deyişle, kronobiyolojik çalışmalar yüklenmeye verilen yanıtlardaki değişkenlikler üzerinde odaklanmıştır (Hill \& Smith1991; Atkinson \& Reilly 1996; Reilly, Atkinson \& Waterhouse 1997; Deschodt \& Arsac 2004; Souissi 2004; Nicolas 2008; Reilly 2009; Rossi 2015; Thun 2015; Cristancho 2016; Ghattassi 2016; Hatfield, Nicoll \& Kraemer 2016; Rosa 2016). Yüklenme sonrası toparlanma sürecine ilişkin olarak diurnal değişimlerin incelendiği bilimsel araştırma sayısı ise oldukça azdır (Güneş 1998; Güvenç 2004; Nicolas 2007; Waterhouse 2007; Morris 2009). Yukarıda belirtilen gerekçelerden dolayı, yüklenme ve yüklenme sonrasındaki toparlanma sürecine ilişkin diurnal değişkenliğin incelendiği bu çalışmanın mevcut literatüre katkı sağlayabileceği düşünülmektedir. Buradan hareketle bu çalışmanın amacı, yüksek şiddetli kısa süreli yüklenme yanıtlarında ve sonrasındaki toparlanma döneminde diurnal değişkenliklerin incelenmesidir.

\section{Yöntem}

\section{Araştırma Grubu}

Araştırmaya yaşları 18 - 22 yıl arasında değişen ve en az 2 yıldır düzenli antrenman yapan 27 sağlıklı erkek sporcu gönüllü olarak katılmıştır. Araştırmaya katılan sporcuların spor dallarına göre dağllımı ise Futbol ( $n=13)$, Basketbol $(n=6)$, Hentbol $(n=4)$, Atletizm $(n=2)$ ve Güreş $(n=2)$ şeklindedir. Araştırma grubunu oluşturan katılımcılar, Beden Eğitimi Spor Yüksekokulu öğrencileri ve öğrenci adayları arasından vücut kütle indeksi $18.5-24.9 \mathrm{~kg} / \mathrm{m}^{2}$ aralı̆̆ında ve gönüllü olarak araştırmaya katılmak isteyip, en az 2 yıl antrenman yaşına sahip olanlardan oluşturulmuştur. Ayrıca araştırma grubunu oluşturan sporculara çalışma hakkında daha önceden ayrıntılı bilgi verilmiş ve çalışmaya gönüllü olarak katılmak isteyenlerden onam formu alınmıştır.

\section{Araştırma Düzeni}

Bu çalışmada takip edilen araştırma düzeni Fig. 1'de görülmektedir. Buna göre, araştırmaya katılan sporcular rastgele yöntemle grup $1\left(\mathrm{G}_{1}\right)$, grup $2\left(\mathrm{G}_{2}\right)$ ve grup $3\left(\mathrm{G}_{3}\right)$ olmak üzere üç gruba ayrılmıştır. Fig. 1'de de görüldüğü gibi her bir farklı grubu oluşturan denekler ikişerli halde değişken ve döngülü olarak her biri farklı saatlerde ve farklı günlerde olmak üzere gün içi 5 farklı saatte aynı ölçümlere alınmışlardır. Bu şekilde, araştırma düzeni olarak kronobiyoloji çalışmalarında sıklıkla kullanılan (Reilly, Atkinson \& Waterhouse 1997) transfer araştırma düzeni kullanılmıştır (Fig.1).

\begin{tabular}{|c|c|c|c|c|c|c|c|c|c|c|c|c|c|c|c|}
\hline \multirow{5}{*}{$\begin{array}{l}08:^{00}-09:^{00} \\
10:^{00}-11:^{00}\end{array}$} & \multicolumn{7}{|c|}{ Rastgele Yöntemle Olușturulmuș Gruplar } & \multicolumn{2}{|l|}{$n=27$} & \multicolumn{3}{|c|}{$G_{1}-G_{2}-G_{3}$} & \multirow[b]{2}{*}{$\mathrm{G}_{1}$} & \multirow[b]{2}{*}{$\mathrm{G}_{2}$} & \multirow[b]{2}{*}{$\mathrm{G}_{3}$} \\
\hline & $\mathbf{G}_{1}$ & $\mathbf{G}_{2}$ & $\mathrm{G}_{3}$ & $\mathbf{G}_{1}$ & $\mathrm{G}_{2}$ & $\mathrm{G}_{3}$ & $\mathbf{G}_{1}$ & $\mathrm{G}_{2}$ & $\mathbf{G}_{3}$ & $\mathbf{G}_{1}$ & $\mathbf{G}_{2}$ & $\mathrm{G}_{3}$ & & & \\
\hline & 1.Gün & 2.Gün & 3.Gün & 4.Gün & 5.Gün & 6.Gün & 7.Gün & 8.Gün & 9.Gün & $10 . \mathrm{GUT}$ & 11.Gün & 12.Gün & 13.Gün & 14.Gūn & 15.Gün \\
\hline & $\mathrm{G}_{1}(1.2)$. & $\mathrm{G}_{2}(1.2)$. & $G_{3}(1.2)$. & $\mathrm{G}_{1}$ (3.4.) & $\mathrm{G}_{2}$ (3.4.) & $\mathrm{G}_{3}($ 3.4.) & $\mathrm{G}_{1}$ (5.6.) & $\mathrm{G}_{2}(5.6)$. & $G_{3}(5.6)$. & $\mathrm{G}_{1}(7.8)$. & $\mathrm{G}_{2}$ (7.8.) & $\mathrm{G}_{3}(7.8)$. & $\mathrm{G}_{1}(9.10)$. & $\mathrm{G}_{2}(9.10$. & $\mathrm{G}_{3}(9.10)$. \\
\hline & $\mathrm{G}_{1}(3.4)$. & $\mathrm{G}_{2}($ 3.4.) & $G_{3}(3.4)$. & $\mathrm{G}_{1}(1.2)$. & $\mathrm{G}_{2}(1.2 .2)$ & $G_{3}(1.2)$. & $\mathrm{G}_{1}(9.10)$. & $\mathrm{G}_{2}(9.10)$. & $\mathrm{G}_{3}(9.10)$. & $\mathrm{G}_{1}(\mathbf{5 . 6 .})$ & $\mathrm{G}_{2}(5.6)$. & $G_{3}(5.6)$. & $\mathrm{G}_{1}(7.8)$. & $\mathrm{G}_{2}(7.8)$. & $G_{3}(7.8)$. \\
\hline $12:^{00}-13:^{00}$ & $\mathrm{G}_{1}(5.6)$. & $\mathrm{G}_{2}(\mathbf{5 . 6 .})$ & $G_{3}(5.6)$. & $\mathrm{G}_{1}(7.8)$. & $\mathrm{G}_{2}(7.8)$. & $G_{3}(7.8)$. & $\mathrm{G}_{1}(1.2)$. & $\mathrm{G}_{2}(1.2)$. & $G_{3}(1.2)$. & $\mathrm{G}_{1}(9.10)$. & $\mathrm{G}_{2}(9.10)$. & $\mathrm{G}_{3}(9.10)$. & $\mathrm{G}_{1}(3.4)$. & $\mathrm{G}_{2}(3.4)$. & $\mathrm{G}_{3}(3.4)$. \\
\hline $15:^{00}-16:^{00}$ & $\mathrm{G}_{1}(7.8)$. & $\mathrm{G}_{2}(7.8)$. & $\mathrm{G}_{3}(7.8)$. & $\mathrm{G}_{1}(9.10)$. & $\mathrm{G}_{2}(9.10)$. & $\mathrm{G}_{3}(9.10)$. & $\mathrm{G}_{1}$ (3.4.) & $\mathrm{G}_{2}(3.4)$. & $\mathrm{G}_{3}(3.4)$. & $\mathrm{G}_{1}(1.2)$. & $\mathrm{G}_{2}(1.2)$. & $\mathrm{G}_{3}(1.2)$. & $\mathrm{G}_{1}(5.6)$. & $\mathrm{G}_{2}(5.6)$. & $G_{3}(5.6)$. \\
\hline \multirow[t]{2}{*}{$17:^{00}-18:^{.0}$} & $\mathrm{G}_{1}(9.10)$. & $\mathrm{G}_{2}(9.10)$. & $G_{3}(9.10)$. & $\mathrm{G}_{1}(\mathbf{5 . 6 .})$ & $\mathrm{G}_{2}(\mathbf{5 . 6 . )}$ & $\mathrm{G}_{3}(\mathbf{5 . 6 . )}$ & $\mathrm{G}_{1}($ 7.8.) & $\mathrm{G}_{2}(7.8)$. & $G_{3}(7.8)$. & $\mathrm{G}_{1}$ (3.4.) & $\mathrm{G}_{2}$ (3.4.) & $\mathrm{G}_{3}($ 3.4.) & $\mathrm{G}_{1}(1.2)$. & $\mathrm{G}_{2}(1.2)$. & $G_{3}(1.2)$. \\
\hline & $\begin{array}{l}\mathrm{G}_{1}= \\
\mathrm{G}_{2}= \\
\mathrm{G}_{1}=\end{array}$ & $\begin{array}{l}\text { Grup 1 } \\
\text { Grup 2 } \\
\text { Grup } 3\end{array}$ & & \multicolumn{4}{|c|}{$\begin{array}{l}\text { (1.2.) }=\text { Birinci ve İkinci Denek } \\
\text { (3.4.) = Ücünncü ve Dördüncü Denek } \\
\text { (5.6.) = Beșinci ve Alttncı Denek }\end{array}$} & \multicolumn{5}{|c|}{$\begin{array}{l}(7.8 .)=\text { Yedinci ve Sekizinci Denek } \\
(9.10 .)=\text { Dokuzuncu ve Onuncu Denek }\end{array}$} & & & \\
\hline
\end{tabular}

Fig. 1. Araştırma Düzeni 
Fig. 1'de de görüldüğü üzere ölçümler transfer araştırma düzenine uygun olacak şekilde, $08:^{00}$ $09:^{00}, 10:^{00}-11:^{.0}, 12:^{00}-13:^{00}, 15:^{.0}-16:^{00}$ ve $17::^{00}-18:^{00}$ saatlerinde olmak üzere günün 5 farklı zamanında tekrar edilmiştir. Bu tip bir araştırma düzenin kullanılmasıyla birlikte; ölçümlerin her defasında tamamlanması gereken 1 saatlik zaman diliminin dışına çıkılmaması ve ölçüm saatlerinin hassas bir şekilde ayarlanması, her bir deneğin ölçümler arasında 72 saat dinlendirebilmesi ve yeterli toparlanmanın sağlanması, her bir ölçüm saatine ilk olarak alınan denek grubunun farklı olmasıyla birlikte testlerde öğrenme etkisinin azaltılması sağlanmıştır. Diğer taraftan bu araştırma başlangıçta 30 sporcu ile başlatılmış ancak tekrar eden ölçümlerin 3 sporcuda tam olarak alınamaması nedeniyle araştırma 27 sporcu ile tamamlanmıştır.

\section{Verilerin Toplanması}

\section{Antropometrik Özellikler}

Boy uzunluğu ölçümleri stadiometre (Holtain Ltd. UK) kullanılarak $\pm 1 \mathrm{~mm}$ hata ile deneğin vücut ağırlığı iki ayağa eşit olarak dağılmış, topuklar birleşik ayaklar çıplak ve baş Frankfort düzleminde iken yapılmıştır. Vücut ağırlığı $\pm 0.1 \mathrm{~kg}$ hata ile ve vücut yağ yüzdesi (VYY), yağsız vücut kütlesi (YVK) ve toplam vücut suyu (TVS) ölçümleri denekler hafif ağırlıkta giysili (şort, atlet) ve ayaklar çıplak şekilde biyoelektrik impedans analizi (Tanita TBF-300, Japan) ile gerçekleştirilmiştir. Vücut kitle indeksi (VKİ) değerleri; "vücut ağırlı̆̆ $(\mathrm{kg})$ / boy uzunluğu $\left(\mathrm{m}^{2}\right)$ " eşitliği kullanılarak hesaplanmıştır. Biyoelektrik impedans analizi ölçümleri sırasında üretici firmanın tavsiye ettiği standart prosedürler dikkate alınmış, ayakların konulduğu çelik skala nemli bir bezle silinerek iletkenlik arttırılmış ve ölçümden önce bireylerden 2 saat süreyle bir şey yememeleri ve boşaltım gereksinimlerini karşılamaları, test öncesi sıvı tüketmemeleri istenmiştir. Vücut ağırlığı ölçümleri her bir deneğe yapılmış olan 5 farklı ölçümde de tekrarlanmış ve anaerobik performans testinde uygulanan test yükleri deneğin o günkü vücut ağırlığına göre hesaplanmıştır.

\section{Kısa Süreli ve Yüksek Şiddetli Yüklenme Protokolünün Uygulanması}

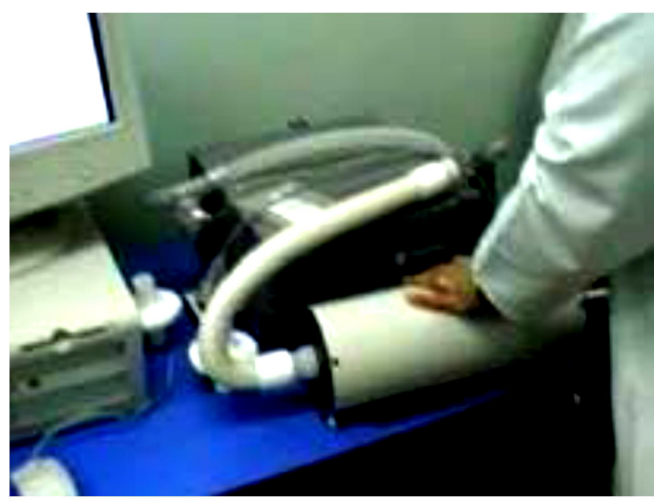

Fig. 2. Solunum Ölçüm Sistemi Kalibrasyonu

Ön Hazırlıklar: Yüklenme protokolü öncesi hazırlık safhasında solunum ölçüm sistemi (Sensor Medics Vmax Spectra 229v, USA) için gerekli kalibrasyonlar (referans gaz ve insprasyon-eksprasyon kalibrasyonu) üretici firmanın kullanım kılavuzunda açıkladığı prosedürlere uyularak ve belirtilen sıklıklarda yapılmıştır (Fig. 2). Kalibrasyon ve ölçümlerden en az 30 dakika önce sistem çalıştırılarak solunum ölçüm cihazının elektrodunun ısınması sağlanmıştır. Yüklenme protokolünün uygulanması için laboratuar aynı oda sicaklığında $\left(20-23 \mathrm{C}^{\circ}\right)$ ve nem miktarında (\% 50'nin üzerinde olmayacak şekilde) hazırlanmıştır. Test öncesi denek uygulanacak protokol ile ilgili ayrıntılı bir şekilde bilgilendirilmiştir. Daha sonra dinlenik ölçümleri alınmak üzere, öncelikle kalp atım hızı bilgilerini kayıt ve monitörize etmek için unipolar özellikte olan 12 kanallı kardiyovasvüler derivasyonları monitörize edebilen (Cardiosoft ECG GE systems Corina 2003, GER) elektrokardiyografi cihazının elektrotları deneğin üzerine; 1. elektrot sternumun sağ dördüncü interkostal aralık ile kesiştiği yere, 2. elektrot sternumun sol dördüncü interkostal aralık ile kesiştiği yere, 4. elektrot sol midklavikuler hattın beşinci interkostal aralık ile kesiştiği yere, 3.elekrot 2. ve 4. elekrotların arasına, 5. elektrot ön koltuk çizgisinin beşinci interkostal aralık ile kesiştiği yere ve 6. elektrot 
arka koltuk çizgisinin beşinci interkostal aralık ile kesiştiği yere gelmesi sağlanacak şekilde hassas bir biçimde yerleştirilmiştir (Fig. 3). Solunum ölçümleri için öncelikle cihazla birlikte kurulan Vmax yazılımına ölçüm yapılacak deneğin vücut ağırlığı, yaşı, cinsiyeti ve 1rksal özellikleri girildikten sonra deneğin yüzüne uygun olan ölçüdeki maske takılarak sabitlenmiştir. Denek bu aşamalar tamamlandıktan sonra rahat bir şekilde sırtüstü yatar pozisyonda dinlenim konumuna geçirilmiş ve daha sonra elektronik sfigmomanometre'nin manşeti deneğin üst kol kısmına takılmıştır (Fig. 3).

Dinlenme Periyodu: Denek dinlenik kalp atım hızı, solunum ve kan basıncı değerlerinin belirlenebilmesi için 10 dakika boyunca sirtüstü yatar pozisyonda bekletilmiştir (Aslan 2013). Kan basıncı ölçümleri osilometrik yöntem ile ölçüm yapan elektronik sfigmomanometre (Braun BP5900) kullanılarak yapılmıştır. Kan basıncı ölçümleri, ölçüm yapılan kol tamamen çıplak haldeyken, dirsek kıvrımının 2-3 cm yukarısına elektronik sfigmomanometre'nin manşeti kola tam oturacak şekilde yerleştirilerek yapılmıştır. Buradan sistolik kan basıncı ve diastolik kan basıncı değerleri kayıt edilmiştir ve ortalama kan basıncı (OKB) değerleri; $\mathrm{OKB}=$ diastolik kan basınc1 + (sistolik kan basınc1 - diastolik kan basıncı) / 3 formülü ile hesaplanmıştır. Bu aşamada ayrıca vücut sıcaklığının ölçülebilmesi için kulaktan timpanik membran üzerinden kızıl ötesi 1şık göndererek ölçüm yapan timpanik termometre (Thermo- Scan0297) kullanılmıştır. Tüm ölçümlerde termometre dış kulağın 1/3'lük kısmına yerleştirilerek, kulak kepçesi yukarı ve alına doğru çekilmiş sinyal sesi gelinceye kadar beklenilerek ölçülen değer ${ }^{0} \mathrm{C}$ cinsinden kaydedilmiştir. Timpanik zarın, ısı merkezi hipotalamus ile aynı kanı paylaşmasından dolayı timpanik termo-

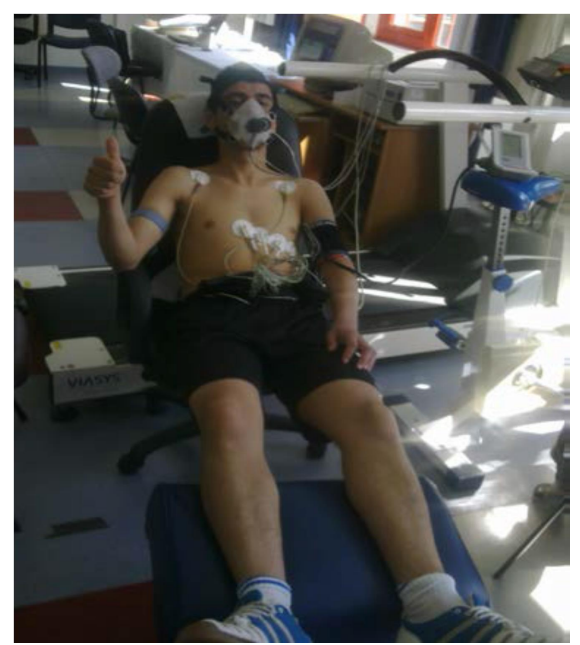

Fig. 3. Dinlenme ve Toparlanma Periyodu metre ile elde edilen vücut sıcaklığı değerlerinin vücut çekirdek sıcaklığına en yakın değerlerden biri olduğu bildirilmektedir (Martin \& Thompson 2000).

Yüklenme Periyodu: Dinlenik veriler kaydedildikten sonra yüklenme protokolü olarak kullanılan Wingate Anaerobik Güç Testi (WAnT) uygulamasına geçilmiştir (Fig. 4). WAnT için optik tur sayaçlı Monark 824E kefeli bisiklet ergometresi (Monark-Crescent AB, Varberg, Sweden), kişisel bilgisayar, Wingate v 1.1 test yazılımı ve $1 \mathrm{~kg}$ 'dan 100 gr'a kadar test ağırlıkları kullanılmıştır. Tüm testler, her tekrarında yukarıda bahsedilen standart laboratuar koşullarında ve aynı işlem yoluyla yapılmıştır. Ayrica test öncesinde bisiklet ergometresinde her denek için ayrı ayrı oturma yüksekliği ayarları yapılmış ve tüm testlerde kaydedilen aynı ayarlar kullanılmıştır. Isınma, bisiklet ergometresinde herhangi bir direnç uygulanmaksızın, pedal hızı dakikada 60-70 devir olacak şekilde ve aralarda 2-3 saniyelik iki kısa yüklenmenin yer aldığı 3 dakikalık sabit bir protokol şeklinde uygulanmıştır (Güvenç 2011). Isınma ve bisiklet ergometresine alışma sonrası denekler beş dakika dinlendirilmiş ve dinlenme sonrası deneklerin ayakları klipsler yardımı ile pedallara sabitlenmiştir. Deneklerden, bisiklet ergometresinin pedalını test boyunca olabildiğince hızlı çevirmeleri istenmiş ve denek olabildiğince hızlandığında (3-4 saniye kadar) vücut ağırlığının kilogramı başına 75 gr olan test yükü bisiklet kefesine bırakılarak 30 saniyelik test gerçekleşmiştir. WAnT'de ulaşılan hız (m/sn) ve 30 saniye boyunca kat edilen mesafe (m) optik tur sayacı ile belirlenmiştir. Anaerobik güç testteki en yüksek güç çıktısı, anaerobik kapasite 30 saniyelik test süresince elde edilen ortalama güç çıktısı ve minimum güç testteki en düşük güç çıktısı olarak absolut ve relatif (absolut değerlerin vücut ağırlığına oranı) değerler şeklinde tespit edilmiştir. Yorgunluk indeksi değerleri 
ise [(anaerobik güç-minimum güç)*100/ anaerobik güç] eşitliğinden hesaplanmıştır.

Otuz saniyelik WAnT yüklenme protokolünün hemen ardından deneğe herhangi bir soğuma protokolü uygulanmaksızın tekrar sırtüstü yatar pozisyonunu alması sağlanmış ve hemen test sonu timpanik vücut sıcaklığı ve kan basıncı ölçümleri alınmıştır. Deneklerin kalp atım hızı ve solunum verileri Vmax bilgisayar yazılımı aracilığıla dinlenimde, yüklenme protokolü süresince ve 21 dakikalık toparlanma periyodu süresince sürekli olarak takip edilerek kaydedilmiştir. $\mathrm{Bu}$ işlemler her bir denek için yukarıda gösterilen araştırma düzeninde (Fig. 1), günün beş farlı saat diliminde ve aynı işlem yolları kullanılarak standart laboratuar ortamında tekrar edilmiştir.

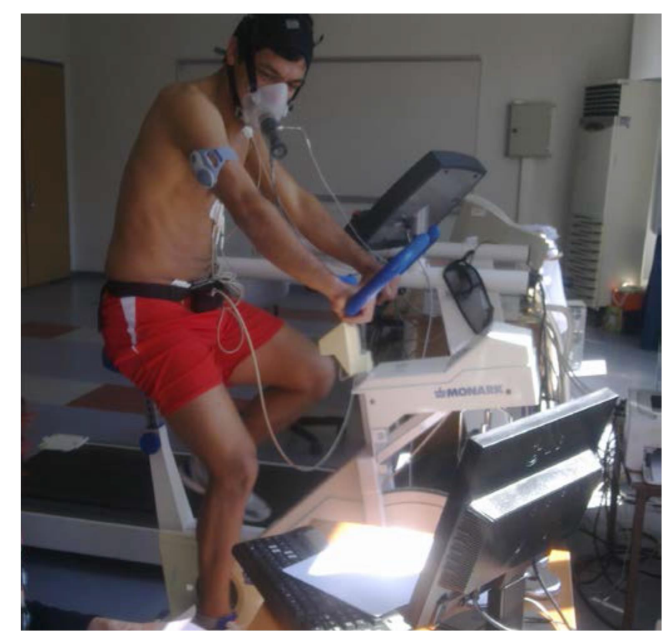

Fig. 4. Test Aşaması

\section{Verilerin Değerlendirilmesi}

Toplanan veriler Excel programında bir araya getirilerek, aşağıdaki işlem sırası izlenmiştir. Kalp atım hızı ve solunum değerleri 10 dakika dinlenme süresince kaydedilmiş ve son 5 dakika ortalamalar dinlenik değerler olarak kullanılmıştır. Vücut s1caklığı ve kan basıncı da yine aynı dinlenme periyodu süresince 1 dakikalık aralarla ölçülmüş ve son 5 dakika ortalama dinlenik değerler kullanılmıştır. Yüklenme protokolünün hemen sonunda alınan kan basınc1 ve vücut sıcaklığı değerleri yüklenmeye yanıt değerler olarak değerlendirilmiştir. Yüklenme protokolü süresince kayıt edilen en yüksek kalp atım hızı ve solunum değerleri yüklenmeye yanıt değerler olarak ele alınmıştır.

Toparlanmada ise kalp atım hız1 ve solunum verilerinin; 3., 6., 9., 12., 15., 18., ve 21. dakikalardaki birer dakikalık ortalamaları dikkate alınmıştır. Kan basıncı ve vücut sıcaklığında ise yine aynı dakikalarda birer ölçüm yapılmıştır. Ayrıca, kalp atım hızı ve solunum verileri için toparlanma oranları (\%); [(yüklenme değerleri - dinlenik değerler) - (ilgili toparlanma değerleri dinlenik değerler) * 100 / (yüklenme değerleri - dinlenik değerler)] formülü yardımıyla hesaplanmıştır (Aslan 2011).

\section{Verilerin Analizi}

Tüm değişkenler için tanımlayıcı istatistik değerler (aritmetik ortalama \pm standart sapma) hesaplanmıştır. Günün beş farlı zamanında tekrarlanan ölçümlerin karşılaştırılmasında Tekrarlı Ölçümlerde Tek Yönlü Varyans Analizi kullanılmıştır. Tekrarlanan ölçümler arasında farklılık anlamlı çıktığında ikişerli karşılaştırmalar Bonferroni yöntemi ile yapılmıştır. Uygulanan istatistiksel işlemlerde $\alpha=0.01$ ve $\alpha=0.05$ yanılma düzeyleri dikkate alınmıştır. Tüm istatistiksel analizler SPSS istatistik paket programında yapılmıştır.

\section{Bulgular}

Çalışmaya yaşları 18-22 yıl arasında değişen (ortalama yaş: $19.46 \pm 1.27$ yıl) ve en az 2 yıl antrenman yaşına sahip olan 27 erkek sporcu katılmıştır. Araştırma grubunu oluşturan sporcuların fiziksel özelliklerine ilişkin tanımlayıcı istatistik değerler Tablo 1'de görülmektedir.

Tablo 1. Araştırma Grubuna İlişkin Fiziksel Özellikler 


\begin{tabular}{|l|c|c|c|}
\hline Fiziksel Özellikler (n=27) & Aritmetik Ortalama \pm Standart Sapma & Minimum & Maksimum \\
\hline Yaş (yıl) & $19.46 \pm 1.27$ & 18.00 & 22.00 \\
\hline Antrenman Yaşı (yıl) & $5.46 \pm 2.27$ & 2.00 & 10.00 \\
\hline Boy Uzunluğu (cm) & $176.88 \pm 4.78$ & 164.00 & 184.00 \\
\hline Vücut Ağırlı̆̆ (kg) & $70.71 \pm 5.91$ & 58.30 & 82.30 \\
\hline VKİ (kg/m²) & $22.46 \pm 1.61$ & 18.60 & 24.70 \\
\hline VYY (\%) & $10.43 \pm 3.22$ & 4.30 & 17.70 \\
\hline YVK (kg) & $62.76 \pm 4.96$ & 51.80 & 72.40 \\
\hline TVS (L) & $48.54 \pm 3.63$ & 46.08 & 53.00 \\
\hline VKI; vïcus & &
\end{tabular}

VKİ; vücut kütle indeksi, VYY; vücut yağ yüzdesi, YVK; yağsız vücut kütlesi, TVS; toplam vücut suyu

Gün içerisinde farklı zamanlarda kaydedilen WAnT sonuçları ve bunlara ilişkin istatistik analizler Tablo 2'de sergilenmiştir.

Tablo 2. Anaerobik Güç, Kapasite ve Yorgunluk İndeksi Değerlerinde Diurnal Değişim

\begin{tabular}{|c|c|c|c|c|c|c|}
\hline WAnT Sonuçları (n=27) & $\begin{array}{c}\text { 1.Ölçüm } \\
\left(08:^{00}-09::^{00}\right)\end{array}$ & $\begin{array}{c}\text { 2.ÖIçüim } \\
\left(10:^{00}-11:^{.00}\right)\end{array}$ & $\begin{array}{c}\text { 3.Ölçüm } \\
\left(12:^{00}-13:^{00}\right)\end{array}$ & $\begin{array}{c}\text { 4.Ölçüm } \\
\left(15:^{.0}-16:^{00}\right)\end{array}$ & $\begin{array}{c}\text { 5.Ölçüm } \\
\left(17:^{00}-18:^{.00}\right)\end{array}$ & $\mathbf{p}$ \\
\hline Absolut Anaerobik Güç (W) & $837.1 \pm 130.2$ & $831.8 \pm 113.6$ & $826.5 \pm 112.4$ & $843.0 \pm 110.8$ & $859.5 \pm 122.8$ & 0.106 \\
\hline Relatif Anaerobik Güç $\left(\mathrm{W} \cdot \mathrm{kg}^{-1}\right)$ & $11.74 \pm 1.12$ & $11.67 \pm 0.93$ & $11.61 \pm 1.08$ & $11.82 \pm 1.03$ & $12.03 \pm 1.21$ & 0.234 \\
\hline Absolut Anaerobik Kapasite (W) & $608.2 \pm 87.8$ & $615.2 \pm 76.2$ & $622.1 \pm 87.3$ & $619.6 \pm 62.1$ & $617.0 \pm 58.3$ & 0.686 \\
\hline $\begin{array}{l}\text { Relatif Anaerobik Kapasite } \\
\left(\mathrm{W} \cdot \mathrm{kg}^{-1}\right)\end{array}$ & $8.54 \pm 1.15$ & $8.65 \pm 0.97$ & $8.75 \pm 1.08$ & $8.71 \pm 1.01$ & $8.68 \pm 1.24$ & 0.560 \\
\hline Absolut Minimum Güç (W) & $361.2 \pm 73.0$ & $377.9 \pm 59.5$ & $394.5 \pm 75.5$ & $388.4 \pm 46.3$ & $382.3 \pm 57.5$ & 0.107 \\
\hline Relatif Minimum Güç (W.kg $\left.{ }^{-1}\right)$ & $5.09 \pm 0.93$ & $5.33 \pm 0.80$ & $5.57 \pm 1.10$ & $5.49 \pm 0.82$ & $5.41 \pm 1.06$ & 0.233 \\
\hline Yorgunluk İndeksi (\%) & $56.27 \pm 9.3$ & $54.2 \pm 7.5$ & $52.2 \pm 8.5$ & $53.6 \pm 7.4$ & $55.1 \pm 8.7$ & 0.084 \\
\hline
\end{tabular}

WAnT; Wingate anaerobik test

Tablo 2 incelendiğinde, gerek absolut gerekse relatif anaerobik güç ve anaerobik kapasite değerlerinde ve yorgunluk indeksinde diurnal değişimin istatistiksel anlam düzeyine ulaşmadığ 1 görülmektedir $(\mathrm{p}>0.05)$. Ancak genel anlamda, öğleden sonraki saatlerde kaydedilen anaerobik güç ve anaerobik kapasite değerlerinin sabah saatlerine göre daha yüksek olduğu gözlenmiştir (Tablo 2). Bir başka deyişle, diğer ölçüm saatleri ile karşılaştırıldığında en yüksek absolut ve relatif anaerobik güç değerlerinin $17::^{00}-18:{ }^{00}$ ve $15::^{00}-16:{ }^{00}$ saatlerinde kaydedildiği ve yine en yüksek absolut ve relatif anaerobik kapasite değerlerinin ise $15::^{00}-16:{ }^{00}$ ve $12:{ }^{00}-13:{ }^{00}$ saatlerinde kaydedildiği Tablo 2 incelendiğinde görülebilir.

Araştırma grubunda günün farklı zamanlarında dinlenik, WAnT sırasında ve sonrasındaki toparlanmada kaydedilen KAH değerleri ve bunlara ilişkin istatistik analizler Tablo 3'de görülmektedir.

Tablo 3. Dinlenik, WAnT Sırasında ve Toparlanma Dönemine İlişkin KAH Değerlerinde Diurnal 
Değişim

\begin{tabular}{|c|c|c|c|c|c|c|}
\hline KAH (n=27) & $\begin{array}{c}\text { 1.Ölçüm } \\
\left(08:^{00}-09:{ }^{00}\right)\end{array}$ & $\begin{array}{c}\text { 2.Ölçüm } \\
\left(10:^{00}-11:^{00}\right)\end{array}$ & $\begin{array}{c}\text { 3.Ölçüm } \\
\left(12:^{00}-13:^{00}\right)\end{array}$ & $\begin{array}{c}\text { 4.Ölçüm } \\
\left(15:^{00}-16:^{00}\right)\end{array}$ & $\begin{array}{c}\text { 5.Ölçüm } \\
\left(17:^{00}-18:^{00}\right)\end{array}$ & $\mathbf{p}$ \\
\hline Dinlenik (atım.dk ${ }^{-1}$ ) & $66.74 \pm 10.36$ & $70.15 \pm 8.49$ & $69.48 \pm 8.30$ & $71.32 \pm 7.49$ & $69.00 \pm 9.21$ & 0.291 \\
\hline WAnT KAH (atım.dk ${ }^{-1}$ ) & $177.47 \pm 9.99$ & $182.61 \pm 10.82$ & $183.93 \pm 12.60$ & $185.86 \pm 11.90$ & $184.32 \pm 13.06$ & $0.025^{*}$ \\
\hline Toparlanma 3. dk. (atım.dk ${ }^{-1}$ ) & $102.25 \pm 12.37$ & $109.65 \pm 13.16$ & $113.23 \pm 17.76$ & $115.47 \pm 11.94$ & $114.25 \pm 13.16$ & 0.157 \\
\hline Toparlanma 6. dk. (atım.dk $\left.{ }^{-1}\right)$ & $94.62 \pm 9.34$ & $100.98 \pm 9.36$ & $103.52 \pm 12.56$ & $106.40 \pm 9.25$ & $105.80 \pm 9.38$ & 0.086 \\
\hline Toparlanma 9. dk. (atım.dk $\left.{ }^{-1}\right)$ & $92.21 \pm 9.64$ & $99.37 \pm 8.70$ & $102.71 \pm 10.15$ & $104.77 \pm 7.87$ & $103.36 \pm 8.62$ & $0.006^{* *}$ \\
\hline Toparlanma 12. dk. $\left(\right.$ atım. $\left.^{-1}\right)$ & $90.73 \pm 10.79$ & $97.35 \pm 9.59$ & $100.15 \pm 10.44$ & $102.34 \pm 8.53$ & $101.06 \pm 9.16$ & 0.116 \\
\hline Toparlanma 15. dk. $\left(\right.$ atım.dk$\left.^{-1}\right)$ & $88.51 \pm 10.64$ & $94.63 \pm 9.94$ & $96.93 \pm 11.43$ & $99.13 \pm 8.93$ & $97.88 \pm 9.81$ & 0.181 \\
\hline Toparlanma 18. dk. $\left(\right.$ atım. $\left.^{-1}\right)$ & $86.66 \pm 9.43$ & $92.55 \pm 9.57$ & $94.63 \pm 11.50$ & $96.99 \pm 8.39$ & $95.88 \pm 9.32$ & 0.145 \\
\hline Toparlanma $21 . \mathrm{dk} .\left(\mathrm{at} \mathrm{m} \cdot \mathrm{dk}^{-1}\right)$ & $84.21 \pm 9.72$ & $89.50 \pm 9.49$ & $90.97 \pm 11.06$ & $93.49 \pm 8.55$ & $92.54 \pm 8.96$ & 0.629 \\
\hline
\end{tabular}

$* \mathrm{P}<0.05,{ }^{*} \mathrm{P}<0.01, \mathrm{KAH} ;$ kalp atım hızı, WAnT; Wingate anaerobik test

Tablo 3'de görüldüğü gibi, günün beş farklı zamanında kaydedilen dinlenik KAH değerleri arasında anlamlı fark yoktur ( $>0.05)$. Ancak WAnT sirasında kaydedilen en yüksek KAH değerlerinde ölçümler arasında anlamlı fark olduğu belirlenmiştir $(\mathrm{p}<0.05)$. Bu sonuç literatürle de uyumlu olup, öğleden sonra akşamüstü saatlerinde yapılan yüksek şiddetli yüklenmelerde KAH düzeyinin daha yüksek değerler alabildiği bildirilmektedir (Atkinson \& Reilly 1996). Yapılan bu çalışmada da en yüksek KAH değeri ortalaması $185.86 \pm 11.90$ atım.dk ${ }^{-1}$ olarak $15:^{00}-16:^{.00}$ saatleri arasında yapılan WAnT'ne cevaben kaydedilmiş ve bunun $08:^{00}-09:^{.0}$ saatlerinde kaydedilen en yüksek KAH değerlerinden anlamlı ölçüde yüksek olduğu tespit edilmiştir $(\mathrm{p}<0.05)$. Bununla birlikte toparlanmanın 9. dakikasında kaydedilen KAH değerleri açısından da ölçümler arasında anlamlı farklılık vardır ve $15:^{00}-16:^{00}$ saatleri arasında kaydedilmiş KAH değerinin sabah saatlerinde yapılan 1. ve 2. ölçüm değerlerinden $\left(08::^{00}-09::^{.0}\right.$ ve $\left.10::^{00}-11:{ }^{00}\right)$ anlamlı ölçüde yüksek olduğu tespit edilmiştir $(\mathrm{p}<0.05)$. Diğer taraftan, toparlanmanın farklı bölümlerinde kaydedilen KAH değerleri açısından ölçüm saatleri arasında istatistiksel olarak anlamlı farklilık yoktur $(\mathrm{p}>0.05)$.

Bununla birlikte, Tablo 3 ve KAH toparlanma oranlarının verildiği Fig. 5 bir bütün olarak incelendiğinde, öğleden sonra ve akşamüstü saatlerinde yapılan yüksek şiddetli yüklenmelere cevaben en yüksek KAH değerleri ve toparlanmaya ilişkin KAH değerlerinin sabah saatlerinde kaydedilen değerlerden daha yüksek olduğu görülebilir. Başka bir deyişle, öğleden önce sabah saatlerinde yüksek şiddetli yüklenmede ve sonrasındaki toparlanma sürecinde KAH yanıtları daha düşük değerlerde seyretmekte ve toparlanma oranları açısından da KAH sabah saatlerinde daha fazla toparlanma eğilimi göstermektedir (Fig. 5). Nitekim sabah $08::^{00}-09::^{00}$ saatlerinde kaydedilen KAH toparlanma oranları toparlanmanın her 3 dakikası için sırasıyla ele alındığında; $\% 67.9, \% 74.8, \% 77.0, \% 78.3, \% 80.3, \% 82.0$ ve $\% 84.2$ olarak gerçekleşmiştir. Akşamüstü $17:^{00}$ $18:^{00}$ saatlerinde kaydedilen toparlanma oranlar1 ise aynı siralamayla; \%60.8, \%68.1, \%70.2, $\% 72.2, \% 75.0, \% 76.7$ ve $\% 79.6$ 'dır. Buradan da anlaşılacağı gibi, yüksek şiddetli yüklenme sonrasında KAH sabah saatlerinde daha fazla toparlanma eğilimi içerisindedir. 


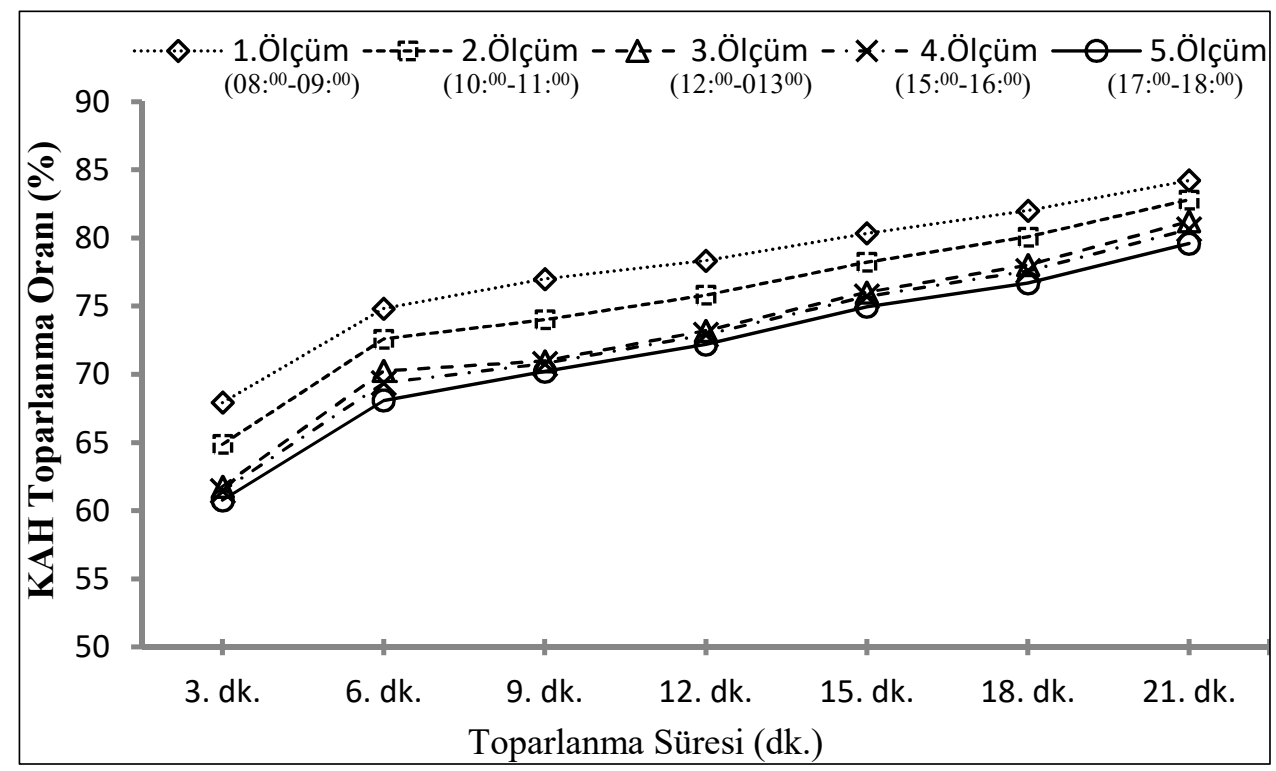

Fig. 5. Wingate Testi Sonrasında KAH Toparlanma Oranlarındaki Diurnal Değişim

Tablo 4'de dinlenik, WAnT sırasında ve sonrasında toparlanma dönemine ilişkin vücut ağırl1ğına oranlı oksijen tüketimi $\left[\mathrm{VO}_{2}\left(\mathrm{ml} . \mathrm{kg}^{-1} \mathrm{dk}^{-1}\right)\right]$ değerlerinde diurnal değişim ve bunlara ilişkin istatistik analizler görülmektedir.

Tablo 4. Dinlenik, WAnT Sırasında ve Toparlanma Dönemine İlişkin Vücut Ağırlığına Oranlı $\mathrm{VO}_{2}$ Değerlerinde Diurnal Değişim

\begin{tabular}{|c|c|c|c|c|c|c|}
\hline $\mathrm{VO}_{2}\left(\mathrm{ml} . \mathrm{kg}^{-1} \mathrm{dk}^{-1}\right)(\mathrm{n}=27)$ & $\begin{array}{c}\text { 1.Ölçüm } \\
\left(08:^{00}-09:^{00}\right)\end{array}$ & $\begin{array}{c}\text { 2.Ölçüm } \\
\left(10:^{00}-11:^{00}\right)\end{array}$ & $\begin{array}{c}\text { 3.Ölçüm } \\
\left(12:^{00}-13:^{00}\right)\end{array}$ & $\begin{array}{c}\text { 4.Ölçüm } \\
\left(15:^{00}-16:^{00}\right)\end{array}$ & $\begin{array}{c}\text { 5.Ölçüm } \\
\left(17:^{00}-18:^{00}\right)\end{array}$ & $\mathbf{p}$ \\
\hline $\left.\mathrm{dk}^{-1}\right)$ & & $2 \pm 1.19$ & $96 \pm 1.96$ & 1 & $4.90 \pm 1.63$ & 0.155 \\
\hline WAnT VO ${ }_{2}\left(\mathrm{ml} . \mathrm{kg} .^{-1} \mathrm{dk}^{-1}\right)$ & .32 & 23 & 7 & 35.70 & $3.17 \pm 6.16$ & 0.118 \\
\hline Tonarlanma $1 \mathrm{dk}\left(\mathrm{ml} \mathrm{ko}^{-1}\right.$ & $2 \pi$ & 32 & 24.1 & 24.9 & 23.75 & 0.072 \\
\hline $\left.\mathrm{dk}^{-1}\right)$ & 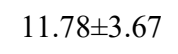 & 13.15 & 12.40 & $13.07=$ & 11.64 & 0.162 \\
\hline $\left.\mathrm{g} \cdot{ }^{-1} \mathrm{dk}^{-1}\right)$ & $47 \pm$ & 8.97 & $9.06=$ & 9.32 & 9.14 & $0.029^{*}$ \\
\hline P & $7.37 \pm 2.29$ & $8.07 \pm 2.03$ & 8.41 & $8.48=$ & $8.15 \pm 2.71$ & 0.051 \\
\hline Toparlanma 12. dk. (ml.kg. $\left.{ }^{-1} \mathrm{dk}^{-1}\right)$ & $6.94 \pm 2.16$ & $7.46 \pm 1.88$ & $7.67 \pm 3.03$ & $7.92 \pm 2.20$ & $7.81 \pm 2.60$ & $0.024^{*}$ \\
\hline oparlanma 15. dk. (ml.kg. $\left.{ }^{-1} \mathrm{dk}^{-1}\right)$ & $6.74 \pm 2.10$ & $7.19 \pm 1.81$ & $7.34 \pm 2.90$ & $7.43 \pm 2.06$ & $7.18 \pm 2.39$ & 0.052 \\
\hline oparlanma 18. dk. (ml.kg. $\left.{ }^{-1} \mathrm{dk}^{-1}\right)$ & $6.27 \pm 1.5$ & $0.10=1.78$ & S & דוע & $6.70 \pm 2.23$ & $0.045^{*}$ \\
\hline ' & 0.001 .03 & 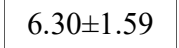 & $0.50 \pm 2.43$ & $6.55 \pm 1.82$ & $6.56 \pm 2.18$ & $0.010^{*}$ \\
\hline
\end{tabular}

$* \mathrm{P}<0.05,{ }^{*} \mathrm{P}<0.01, \mathrm{VO}_{2}\left(\mathrm{ml}_{\mathrm{kg}}{ }^{-1} \mathrm{dk}^{-1}\right)$; relatif oksijen tüketimi ya da vücut ağırlığının kilogramı başına tüketilen oksijen miktarı, WAnT; Wingate anaerobik test

Tablo 4'de görüldüğü gibi gün içerisinde beş farkl1 zamanda kaydedilen dinlenik relatif $\mathrm{VO}_{2}$ değerleri arasında anlamlı fark yoktur $(\mathrm{p}>0.05)$. Aynı şekilde, WAnT sırasında ve sonrasında toparlanma döneminin 1., 3., 9. ve 15. dakikalarında kaydedilen relatif $\mathrm{VO}_{2}$ değerleri açısından da ölçüm saatleri arasında istatistiksel olarak anlamlı farklılık yoktur ( $>0.05)$. Ancak toparlanma döneminin 6., 12., 18. ve 21. dakikalarında kaydedilen relatif $\mathrm{VO}_{2}$ değerleri açısından diurnal değişim anlamlıdır $(\mathrm{p}<0.05)$. Yapılan ikili karşılaştırmalarda, toparlanma döneminin 6 ., 12., 18. ve 21. dakikalarına ilişkin olarak sabah $08::^{00}-09:^{00}$ saatleri arasında kaydedilmiş relatif 
$\mathrm{VO}_{2}$ değerlerinin, $15:^{00}-16:^{00}$ saatleri arasında kaydedilen değerlerden anlamlı ölçüde düşük olduğu tespit edilmiştir $(\mathrm{p}<0.05)$. Bu sonuçlarla birlikte, Tablo 3 'de verilen relatif $\mathrm{VO}_{2}$ değerleri genel olarak incelendiğinde, özellikle toparlanmanın 6. dakikasından sonraki dönemlerde relatif $\mathrm{VO}_{2}$ yanıtları öğleden sonra ve akşamüstü değerlerine göre sabah $08::^{00}-09:{ }^{00}$ saatleri arasında daha düşük değerlerde seyretmekte ve sabah saatlerinde daha fazla toparlanma eğilimi göstermektedir. Ancak relatif $\mathrm{VO}_{2}$ 'ne iliş̧kin toparlanma oranlarının verildiği Fig. 6 incelendiğinde, yukarıda bahsedilen diurnal değişime ilişkin relatif $\mathrm{VO}_{2}$ 'de belirginlik kazanan bir farklılaşma olmadığ görülmektedir (Fig. 6). Nitekim relatif $\mathrm{VO}_{2}$ toparlanma oranları sirasılya ele alınd1ğinda sabah $08::^{00}-09::^{00}$ saatlerinde; \%32.2, \%75.1, \%85.9, \%89.5, \%91.0, \%91.7, \%93.2 ve $\% 93.9$ olarak ve akşamüstü $17::^{00}-18:{ }^{00}$ saatlerinde ise aynı sırayla; \%33.3, \%76.1, \%85.0, \%88.5, \%89.7, \%91.9, \%93.6 ve \%94.1 olarak gerçekleşmiştir.

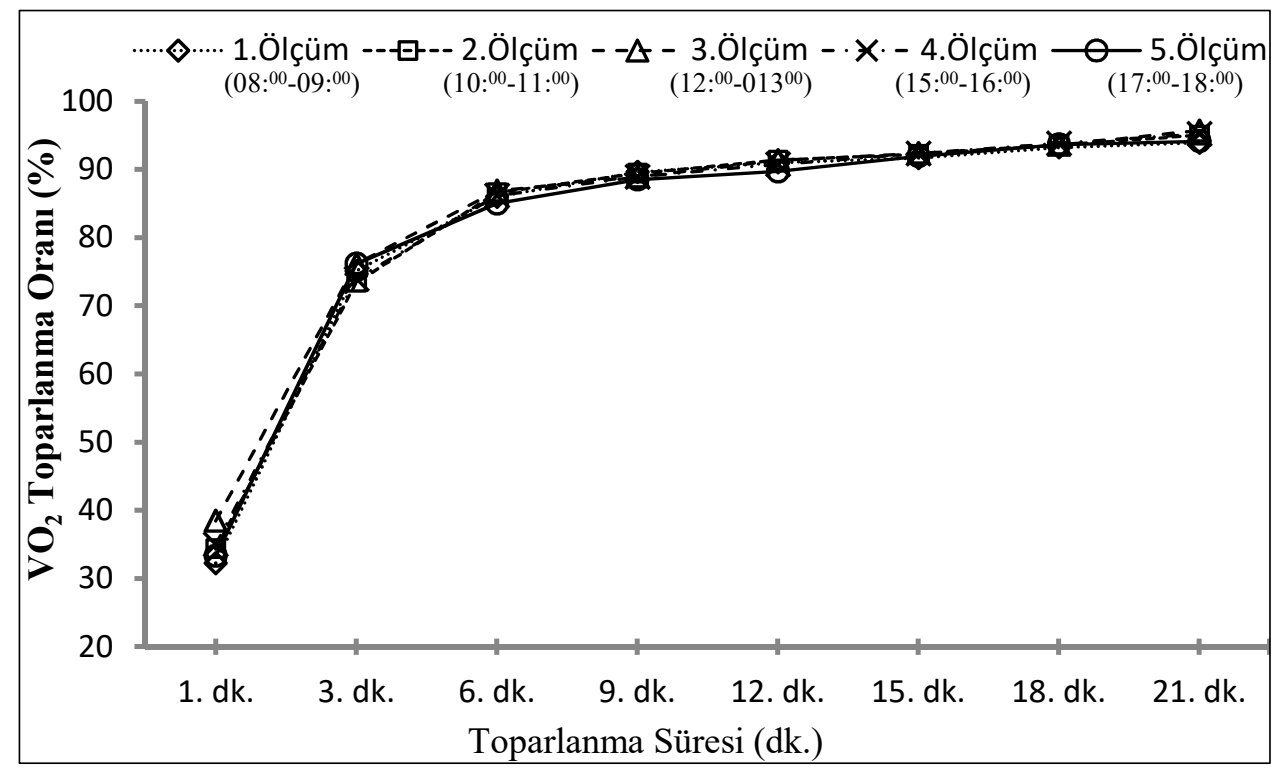

Fig. 6. Wingate Testi Sonrasında Relatif $\mathrm{VO}_{2}$ Toparlanma Oranlarındaki Diurnal Değişim

Tablo 5'de deneklerin yüklenme öncesindeki dinlenik ve ilki hemen WAnt testi bitiminde olmak üzere toparlanmada 3'er dakikalık aralarla ölçülmüş olan timpanik vücut sıcaklığı değerleri ve bunlara ilişkin istatistik analiz sonuçları sergilenmiştir.

Tablo 5. Dinlenik, WAnT Sonrası ve Toparlanma Dönemine İlişkin Vücut Sıcaklığı Değerlerinde Diurnal Değişim

\begin{tabular}{|c|c|c|c|c|c|c|}
\hline Vücut Sıcaklığı $(n=27)$ & $\begin{array}{c}\text { 1.Ölçüm } \\
\left(08:^{00}-09:^{00}\right)\end{array}$ & $\begin{array}{c}\text { 2.Ölçüm } \\
\left(10:^{00}-11:^{00}\right)\end{array}$ & $\begin{array}{l}\text { 3.Ölçüm } \\
\left(12:^{.0}-13:^{.0}\right)\end{array}$ & $\begin{array}{c}\text { 4.Ölçüm } \\
\left(15:^{00}-16:^{00}\right)\end{array}$ & $\begin{array}{c}\text { 5.Ölçüm } \\
\left(17:^{00}-18:^{00}\right)\end{array}$ & $\mathbf{p}$ \\
\hline Dinlenik $\left({ }^{0} \mathrm{C}\right)$ & $36.17 \pm 0.98$ & $36.28 \pm 1.04$ & $36.39 \pm 1.21$ & $36.33 \pm 0.98$ & $36.28 \pm 1.05$ & 0.056 \\
\hline WAnT Sonras $\left({ }^{0} \mathrm{C}\right)$ & $36.30 \pm 0.95$ & $36.46 \pm 0.83$ & $36.63 \pm 0.89$ & $36.58 \pm 0.74$ & $36.54 \pm 1.09$ & $0.002 * *$ \\
\hline Toparlanma 3. dk. $\left({ }^{0} \mathrm{C}\right)$ & $36.40 \pm 0.89$ & $36.55 \pm 0.73$ & $36.69 \pm 0.78$ & $36.67 \pm 0.67$ & $36.66 \pm 1.12$ & $0.009 * *$ \\
\hline Toparlanma 6. dk. $\left({ }^{0} \mathrm{C}\right)$ & $36.43 \pm 0.97$ & $36.54 \pm 0.75$ & $36.65 \pm 0.88$ & $36.65 \pm 0.73$ & $36.64 \pm 1.06$ & 0.133 \\
\hline Toparlanma 9. dk. $\left({ }^{0} \mathrm{C}\right)$ & $36.49 \pm 0.98$ & $36.55 \pm 0.71$ & $36.60 \pm 0.87$ & $36.61 \pm 0.65$ & $36.62 \pm 0.98$ & 0.438 \\
\hline Toparlanma 12. dk. $\left({ }^{0} \mathrm{C}\right)$ & $36.50 \pm 0.94$ & $36.58 \pm 0.77$ & $36.66 \pm 0.83$ & $36.63 \pm 0.68$ & $36.59 \pm 1.01$ & 0.229 \\
\hline Toparlanma $15 . \mathrm{dk} .\left({ }^{0} \mathrm{C}\right)$ & $36.50 \pm 0.99$ & $36.59 \pm 0.67$ & $36.68 \pm 0.61$ & $36.62 \pm 0.61$ & $36.57 \pm 1.04$ & 0.255 \\
\hline Toparlanma $18 . \mathrm{dk} .\left({ }^{0} \mathrm{C}\right)$ & $36.48 \pm 0.92$ & $36.54 \pm 0.71$ & $36.60 \pm 0.79$ & $36.57 \pm 0.63$ & $36.55 \pm 0.93$ & 0.568 \\
\hline Toparlanma 21. dk. $\left({ }^{0} \mathrm{C}\right)$ & $36.39 \pm 0.97$ & $36.44 \pm 0.74$ & $36.49 \pm 0.87$ & $36.53 \pm 0.60$ & $36.56 \pm 0.86$ & 0.399 \\
\hline
\end{tabular}

$* \mathrm{P}<0.05, * * \mathrm{P}<0.01, \mathrm{WAnT}$; Wingate anaerobik test 
Tablo 5 incelendiğinde, dinlenik timpanik vücut sıcaklığı değerlerinde diurnal değişimin anlamlı düzeyde olmadığı görülmektedir $(\mathrm{p}>0.05)$. Ancak, istatistiksel olarak anlamlı fark olmamakla birlikte, Tablo 5'de verilen aritmetik ortalamalar bakımından dinlenik vücut sıcaklığının gün içerisinde öğlen saatlerinde daha yüksek olduğu söylenebilir. Nitekim dinlenik vücut sıcaklığ 1 değerlerinde anlamlılık düzeyine yakın bir değişkenlik gözlenmiştir.

Diğer taraftan, WAnt testi bitiminde ve toparlanma döneminin 3. dakikasında kaydedilen vücut sıcaklığı değerleri açısından diurnal değişim anlamlıdır $(\mathrm{p}<0.01)$. WAnt'nin hemen sonrasında ve toparlanma döneminin 3. dakikasında kaydedilen vücut sıcaklığı değerlerine ilişkin yapılan ikili karşılaştırmalarda, sabah $\left(08::^{00}-09:{ }^{00}\right)$ saatlerinde kaydedilmiş vücut sıcaklığı değerlerinin, öğlen $\left(12:^{00}-13:^{00}\right)$, öğleden sonra $\left(15:^{00}-16:^{00}\right)$ ve akşamüstü $\left(17::^{00}-18:^{00}\right)$ saatlerde kaydedilen değerlerden anlamlı ölçüde düşük olduğu belirlenmiştir $(\mathrm{p}<0.05)$. Bunun dışında toparlanmanın farklı dönemlerinde kaydedilen vücut sıcaklığı değerleri açısından ölçüm saatleri arasinda istatistiksel olarak anlamlı farklılık yoktur $(\mathrm{p}>0.05)$.

Bununla birlikte Tablo 5 ve Fig. 7 genel olarak incelendiğinde, gerek dinlenik ve WAnt'nin hemen sonrasında gerekse toparlanma sürecinin farklı evrelerinde kaydedilen vücut sicaklığ değerlerinin öğlen $\left(12::^{00}-13::^{00}\right)$, öğleden sonra $\left(15::^{00}-16:^{00}\right)$ ve akşamüstü $\left(17::^{00}-18:^{00}\right)$ saatlerine göre sabah $\left(08::^{00}-09:^{00}\right)$ saatlerinde daha düşük düzeyde seyrettiği görülebilir (Fig. 7).

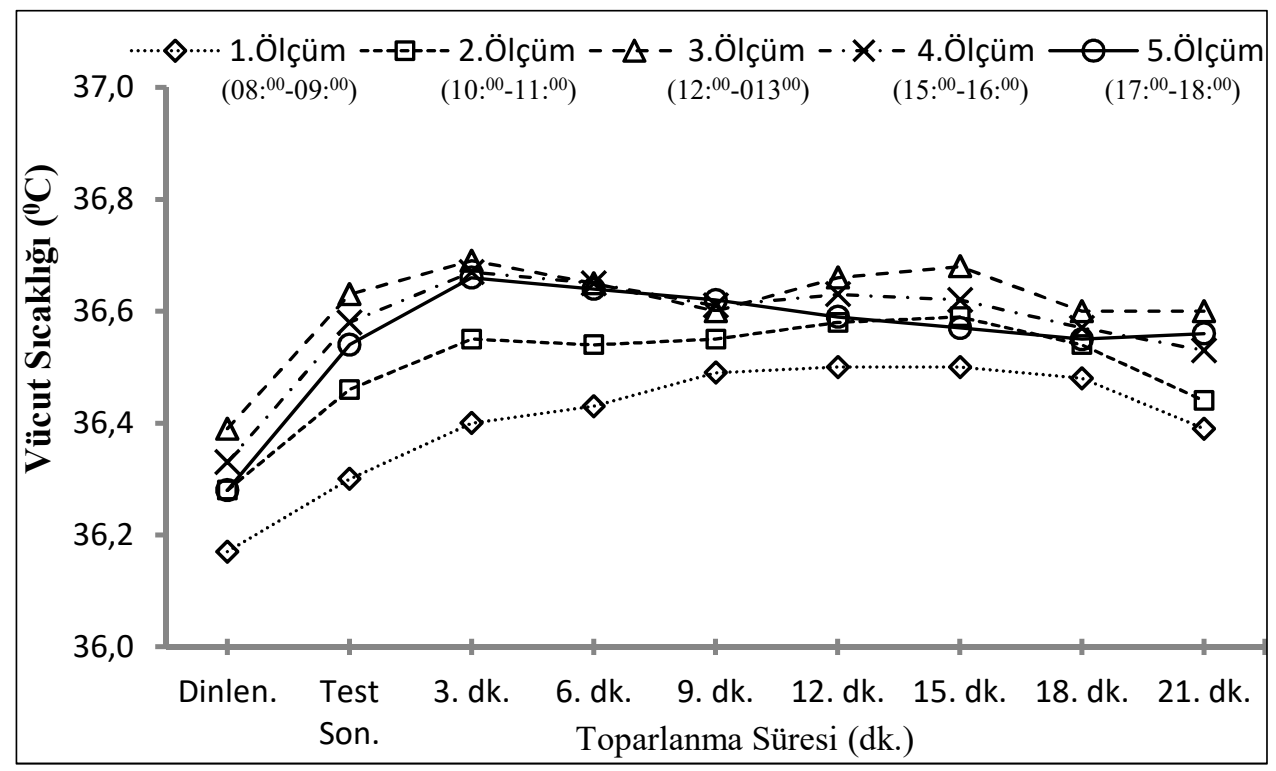

Fig. 7. Dinlenik, Wingate Testi Bitiminde ve Toparlanma Sürecine İlişkin Vücut Sıcaklığı Değerlerindeki Diurnal Değişim

Tablo 6'de deneklerin dinlenik, WAnt'nin hemen sonrasında ve toparlanmanın her 3 dakikasında belirlenen ortalama kan basıncı değerleri ve bunların diurnal değişimine ilişkin istatistik analiz sonuçları verilmiştir.

Tablo 6'de görüldüğü gibi sistolik ve diastolik kan basıncı değerlerinden hesaplanan ve normal değer aralığı 70-100 mmHg olan ortalama kan basıncı ya da ortalama arter basınç değerlerine ilişkin olarak gerek dinlenik ve WAnt'nin hemen sonrasında gerekse toparlanma sürecinin farklı evrelerinde diurnal değişim anlamlı değildir ( $p>0.05)$. 
Tablo 6. Dinlenik, WAnT Sonrası ve Toparlanma Dönemine İlişkin Ortalama Kan Basınc1 Değerlerinde Diurnal Değişim

\begin{tabular}{|c|c|c|c|c|c|c|}
\hline OKB $(n=27)$ & $\begin{array}{c}\text { 1.Ölçüm } \\
\left(08:^{00}-09:^{00}\right)\end{array}$ & $\begin{array}{c}\text { 2.Ölçüm } \\
\left(10:^{00}-11:^{00}\right)\end{array}$ & $\begin{array}{c}\text { 3.Ölçüm } \\
\left(12:^{00}-13:^{00}\right)\end{array}$ & $\begin{array}{c}\text { 4.Ölçüm } \\
\left(15:^{00}-16:^{00}\right)\end{array}$ & $\begin{array}{c}\text { 5.Ölçüm } \\
\left(17:^{00}-18:^{00}\right)\end{array}$ & $\mathbf{p}$ \\
\hline Dinlenik (mmHg) & $.00 \pm 5.94$ & $85.95 \pm 7.13$ & $85.25 \pm 6.65$ & $86.50 \pm 5.18$ & $87.14 \pm 5.71$ & 0.789 \\
\hline WAnT Sonrası (mn & $110.22 \pm 8.81$ & $112.57 \pm 10.11$ & $112.51 \pm 11.33$ & $112.74 \pm 7.91$ & $114.56 \pm 8.72$ & 0.412 \\
\hline Toparlanma 3. dk. (mmHg) & $91.52 \pm 7.22$ & $91.93 \pm 7.44$ & $92.57 \pm 9.32$ & $92.82 \pm 6.51$ & $93.91 \pm 7.15$ & 0.811 \\
\hline Toparlanma 6. dk. (mmHg) & $85.25 \pm 10.07$ & $86.59 \pm 7.68$ & $84.94 \pm 7.07$ & $86.95 \pm 7.50$ & $87.31 \pm 5.85$ & 0.642 \\
\hline Toparlanma 9. dk. (mmHg) & $82.91 \pm 7.50$ & $83.22 \pm 5.69$ & $82.68 \pm 6.40$ & $84.06 \pm 5.62$ & $84.44 \pm 5.10$ & 0.926 \\
\hline Toparlanma 12. dk. (mmHg) & $83.44 \pm 6.51$ & $83.86 \pm 6.60$ & $83.01 \pm 6.90$ & $84.66 \pm 5.60$ & $84.94 \pm 5.52$ & 0.837 \\
\hline Toparlanma 15. dk. (mmHg) & $83.77 \pm 6.85$ & $83.79 \pm 6.89$ & $83.78 \pm 7.30$ & $84.78 \pm 5.87$ & $85.29 \pm 5.92$ & 1.000 \\
\hline Toparlanma 18. dk. (mmHg) & $83.04 \pm 8.75$ & $84.67 \pm 6.45$ & $83.14 \pm 8.28$ & $84.86 \pm 6.54$ & $85.41 \pm 6.20$ & 0.495 \\
\hline Toparlanma 21. dk. (mmHg) & $86.20 \pm 9.03$ & $85.20 \pm 6.48$ & $83.38 \pm 7.17$ & $86.73 \pm 6.86$ & $85.81 \pm 5.63$ & 0.214 \\
\hline
\end{tabular}

$* \mathrm{P}<0.05, * * \mathrm{P}<0.01, \mathrm{OKB}$; ortalama kan basınc1 [OKB=diastolik kan basınc1 + (sistolik kan basınc1 - diastolik kan basinc1) / 3], WAnT; Wingate anaerobik test

\section{Tartışma ve Sonuç}

$\mathrm{Bu}$ çalışmada, kısa süreli yükssek şiddetli yüklenme yanıtlarında ve yüklenme sonrasındaki toparlanma döneminde diurnal ya da gün içi değişkenliklerin incelenmesi amaçlanmıştır. Araştırmaya en az iki yıl antrenman yaşına sahip olan, yaşları 18 - 22 yıl arasında değişen ve farklı spor dalları ile uğraşan 27 erkek sporcu katılmıştır. Araştırma grubunu oluşturan sporculara araştırmanın yöntem bölümünde de açıklanmış olan (Fig. 1), ve kronobiyoloji çalışmalarına özgü olarak kullanılan (Reilly, Atkinson \& Waterhouse 1997) transfer araştırma düzeninde $08:^{00}-09:^{.0}, 10:^{00}-11:^{00}, 12:^{00}-13:^{.0}, 15:^{00}-16:^{.0}$ ve $17:^{00}-18:^{00}$ saatlerinde olmak üzere günün beş farklı zamanında kısa süreli yüksek şiddetli yüklenme protokolü (WAnT) uygulanmıştır. Testten elde edilen anaerobik performans düzeyleri ile birlikte, test öncesi dinlenik, test sirasında ve sonrasındaki 21 dakikalık toparlanma sürecine ilişkin olarak $\mathrm{KAH}, \mathrm{VO}_{2}$, vücut sicaklığı ve ortalama kan basıncı değerlerindeki diurnal değişkenlik değerlendirilmiştir. Kronobiyoloji araştırmalarında sıklıkla kullanılan transfer araştırma düzeninin (Reilly, Atkinson \& Waterhouse 1997) bu çalışmada da kullanılmasıyla birlikte; yukarıda belirtilen ilgili ölçüm saatlerinin hassas bir şekilde takip edilmesi, tekrarlayan testler arasında deneğe yeterli dinlenme süresinin verilebilmesi ve testlere ilişkin olarak öğrenme etkisinin azaltılması sağlanmıştır. Diğer taraftan mevcut literatürde yer alan ve diurnal ya da gün içi değişkenliklerin sportif performans bileşenleri üzerindeki etkilerini araştıran çalışmalar daha çok yüklenmeye verilen yanıtlar üzerinde yoğunlaşmıştır (Hill \& Smith 1991; Atkinson \& Reilly 1996; Reilly, Atkinson \& Waterhouse 1997; Deschodt \& Arsac 2004; Souissi 2004; Nicolas 2008; Reilly 2009; Rossi 2015; Thun 2015; Cristancho 2016; Ghattassi 2016; Hatfield, Nicoll \& Kraemer 2016; Rosa 2016). Ancak yüklenme sonrasındaki toparlanma sürecine ilişkin olarak diurnal salınımların araştırıldığı çalışmalar bunlarla karşılaştırıldığında yetersiz kalmaktadır (Güneş 1998; Güvenç 2004; Nicolas 2007; Waterhouse 2007; Morris 2009). Bundan dolay1, yapılan bu çalışmada özellikle toparlanma dönemindeki diurnal değişkenliklere odaklanılmıştır.

Farklı değişkenlerin dinlenik değerlerine ilişkin olarak bu çalışmadan elde edilen bulgular şu şekilde özetlenebilir; istatistiksel olarak anlamlı bir fark olmamakla birlikte, kaydedilen ortalama değerler bakımından $\mathrm{KAH}$, relatif $\mathrm{VO}_{2}$, vücut sicaklığ 1 ve ortalama kan basıncina ilişkin dinlenik değerler sabah $08:{ }^{00}-09:{ }^{00}$ saatlerinde diğer ölçüm saatlerine göre daha düşük 
düzeydedir ve bu ortalama değerler özellikle öğleden sonra $15:^{00}-16:^{00}$ ve akşamüstü $17::^{00}-18:^{00}$ saatlerinde daha yüksek düzeylerde tespit edilmiştir (Tablo 3, Tablo 4, Tablo 5 ve Tablo 6). Literatürde farklı fizyolojik değişkenlerin dinlenik düzeylerine ilişkin olarak diurnal değişkenliği değerlendiren çalışmalar bulunmaktadır (Atkinson \& Reilly 1996; Reilly, Atkinson \& Waterhouse 1997; Güvenç 2004; Atkinson 2005; Drust 2005; Brisswalter 2007; Morris 2009; Shiotani 2009; Souissi 2010). Bu çalışmalarda benzer olarak, vücut sıcaklığındaki günlük ritimle birlikte $\mathrm{KAH}, \mathrm{VO}_{2}$ ve kan basıncı değerlerinin de akşam ve akşamüstü düzeylerine göre sabah saatlerinde daha düşük dinlenik değerlerde seyrettiği bildirilmektedir (Atkinson \& Reilly 1996; Reilly, Atkinson \& Waterhouse 1997; Güvenç 2004; Atkinson 2005; Drust 2005; Brisswalter 2007; Morris 2009; Shiotani 2009; Souissi 2010). Vücut sıcaklığının gün içerisindeki değişimlerinin araştırıldığı benzer çalışmalarda vücut sıcaklığının sabah erken saatlerden akşamüstü saatlerine doğru yaklaşık $1^{\circ} \mathrm{C}^{\prime} l 1 \mathrm{k}$ bir artış gösterebildiği bildirilmektedir (Atkinson \& Reilly 1996; Reilly, Atkinson \& Waterhouse 1997; Drust 2005). Bu farkın daha az ya da anlamlı düzeyde olmadığı çalışmalarda bulunmaktadır (Booth, Marino \& Ward 1997; Nicolas 2008). Bu çalışmada ise, vücut sıcaklığının gün içerisindeki değişimi dinlenimde $0.22^{\circ} \mathrm{C}$ olmakla birlikte anlamlı diurnal bir etki belirlenmemiştir. Ancak yukarıda da belirtildiği gibi bu çalışmada ele alınan dinlenik fizyolojik yanıtlarda ortalama değerler bakımından sabah $08:^{00}$ 09: ${ }^{00}$ saatlerinde diğer ölçüm saatlerine göre daha düşük düzeylerde olma eğilimi vardır. Farklı sonuçların alınmasında, ölçüm yöntemlerinin değişkenliği ya da araştırma grubu farklılıkları etkili olmuş olabilir.

$\mathrm{Bu}$ çalışmada günün farklı saatlerinde kaydedilen anaerobik performans değerleri ve yüklenme yanıtları ele alındığında ise, kısa süreli yüksek şiddetli yüklenme protokolünde (WAnT) kaydedilen anaerobik performans değerlerine ilişkin diurnal değişim istatistiksel olarak anlamlı değildir. Ancak genel olarak ortalama değerler bakımından, öğleden sonra ve akşamüstü saatlerde kaydedilen anaerobik güç ve anaerobik kapasite değerlerinin sabah saatlerine göre daha yüksek olduğu belirlenmiştir (Tablo 2). Bununla uyumlu olarak, yüklenmeye cevaben elde edilen en yüksek $\mathrm{KAH}$ ve yüklenmenin hemen sonrasındaki vücut sıcaklığ 1 değerlerinde anlamlı ölçüde diurnal değişim gözlenmiştir $(p<0.05)$ ve sabah saatleri $\left(08:{ }^{00}-09:^{00}\right)$ ile karşılaştırıldığında öğleden sonra ve akşamüstü saatlerinde yüklenmeye cevaben kaydedilen KAH ve vücut sıcaklığı değerlerinin daha yüksek olduğu belirlenmiştir (Tablo 3 ve Tablo 5). Diğer taraftan istatistiksel olarak anlamlı bir fark olmamakla birlikte, ortalama değerler bakımından yüklenmenin hemen sonunda kaydedilen ortalama kan basıncı değerleri de sabah saatlerine $\left(08:{ }^{00}-09:{ }^{00}\right)$ göre öğleden sonra ve akşamüstü saatlerde daha yüksektir (Tablo 6). Ancak yüklenme protokolüne cevaben kaydedilen vücut ağırlı̆̆ına oranlı en yüksek $\mathrm{VO}_{2}$ değerlerinde ise anlamlı diurnal değişim yoktur ve günün farklı saatlerinde kaydedilen değerlere ilişkin olarak da belirginlik kazanan bir eğilim gözlenmemiştir (Tablo 4). Literatürde kısa süreli yüksek şiddetli yüklenmelerde kaydedilen performans düzeyleri ve yüklenmeye fizyolojik yanıtlardaki diurnal değişimin değerlendirildiği çalışmalarda genellikle daha yüksek performans değerlerinin öğleden sonra ve akşamüstü saatlerde kaydedildiği yönünde araştırma bulguları mevcuttur (Hill \& Smith1991; Atkinson \& Reilly 1996; Reilly, Atkinson \& Waterhouse 1997; Deschodt \& Arsac 2004; Güvenç 2004; Souissi 2004; Nicolas 2007; Nicolas 2008). Deschodt ve Arsac (2004) yüzücüler üzerinde yapmış oldukları çalışmada, anlamlı fark olmamakla birlikte akşamüstü $18:^{00}$, de kaydedilen bisiklet ergometresi maksimum güç çıktısı düzeyinin sabah $08:^{00}$ deki değerlerden daha yüksek olduğu, akşamüstü yapılan yüklenmelere cevaben vücut sıcaklığının sabah kaydedilen değerlere göre $0.4^{\circ} \mathrm{C}$ daha yüksek olduğu ve yüksek şiddetli yüzme performansı değerlerinin de sabah saatlerine $\left(08:^{00}\right)$ göre akşamüstü $\left(18^{00}\right)$ saatlerinde \%4'lük anlamlı bir artış gösterdiği bildirilmektedir. Nicolas ve arkadaşlarının (2008) erkek sporcular ile yapmış oldukları bir başka 
çalışmada, akşamüstü $18:^{00}$ de kaydedilen izokinetik kuvvet testi sonuçlarının sabah $06:^{00}$ da kaydedilen değerlere göre \% 7.1 oranında daha fazla olduğu, ayn ş̧ekilde akşamüstü $18:^{00}$ de kaydedilen vücut sıcaklığı değerlerinin de sabah saatlerine göre $0.6{ }^{\circ} \mathrm{C}$ daha yüksek olduğu bildirilmektedir. Güvenç'in (2004) erkek sporcularla yaptığı diğer bir çalışmada ise, akşamüstü $17:^{00}-19:^{00}$ saatlerinde kaydedilen anaerobik güç, anaerobik kapasite, dinlenik KAH ve WAnT'deki en yüksek KAH değerlerinin sabah $07::^{30}-09:{ }^{30}$ saatlerindeki değerlerinden anlaml 1 ölçüde yüksek olduğu belirlenmiştir. Kısa süreli maksimal şiddetli yüklenmelerin farklı saat dilimlerinde uygulandığı diğer bir çalışmada da, en düşük performans değerleri ve en düşük dinlenik ve test sonu KAH değerleri saat $08:^{.00}$ de, bunlara ilişkin en yüksek değerler ise saat $18:^{00}$ de belirlenmiştir (Atkinson \& Reilly 1996). Diğer taraftan bazı araştırmacılar yaptıkları çalışmalarda en yüksek $\mathrm{VO}_{2}$ değerlerinin öğleden sonra ve akşamüstü kaydedildiğini bildirirken (Atkinson \& Reilly 1996; Reilly, Atkinson \& Waterhouse 1997), diğer araştırmacılar yapılan bu çalışmaya benzer olarak $\mathrm{VO}_{2}$ değerlerinin gün içerisinde anlamlı farklılık gösterecek salınıma erişmediğini belirtmişlerdir (Akkurt, Gür \& Küçükoğlu 1996). Bununla birlikte literatürde anaerobik güç, anaerobik kapasite değerlerinin ve WAnT'ne cevaben verilen en yüksek fizyolojik cevapların sabah saatlerine göre öğleden sonra ve akşamüstü saatlerinde daha yüksek olduğunu gösteren başka araştırma bulguları da mevcuttur (Hill \& Smith1991; Atkinson \& Reilly 1996; Reilly, Atkinson \& Waterhouse 1997; Souissi 2004; Nicolas 2007). Ancak baz1 araştırma sonuçları da WAnT'de ya da yüksek şiddetli yüklenmelerde kaydedilen performans değerlerinde ve fizyolojik yanıtlarda anlamlı düzeyde diurnal değişim gözlenmediği yönündedir (Morris 2009; Souissi 2010). Souissi ve arkadaşları (2010) sabah ve akşamüstü saatlerinde kaydedilen anaerobik güç ve anaerobik kapasite değerlerinde ve yüklenmeye cevaben alınan rektal vücut sıcaklığı değerlerinde anlamlı ölçüde diurnal değişim olmadığını bildirmektedirler. İlgili literatürde yüklenimde ve yüklenmeye yanıtlarda diurnal değişimin araştırıldığı çalışmalarda farklı sonuçlar elde edilmesinin nedenleri; gün içerisinde farklı saat dilimlerinde ölçümlerin yapılması, 1sınma ve yüklenme biçimlerinin farklılaşması, ölçüm ve değerlendirme yöntemlerinin farklı olması, araştırma grubu farklılıkları ya da iklimsel farklılıklar sonucunda olabilir.

$\mathrm{Bu}$ çalışmada günün beş farklı saatinde tekrarlanmış yüklenme protokolü sonrasındaki 21 dakikalık toparlanma yanıtları ele alındığında ise, hem KAH ve vücut sıcaklığı toparlanma değerlerinin hem de toparlanmanın 3. dakikasından sonraki relatif $\mathrm{VO}_{2}$ değerlerinin öğlen ve öğleden sonraki saatlere göre sabah $08::^{00}-09::^{00}$ saatlerinde daha düşük ortalama değerlerde seyrettiği gözlenmiştir (Tablo 3, Tablo 4 ve Tablo 5). Bununla birlikte KAH toparlanma oranları açısından da sabah saatlerinde $\left(08:^{00}-09::^{00}\right) \mathrm{KAH}$ daha fazla toparlanma eğilimi göstermektedir (Fig. 5). Nitekim sabah $08:{ }^{00}-09:{ }^{00}$ saatlerinde kaydedilen KAH toparlanma oranları toparlanmanın her bir 3 dakikası için sırasıly incelendiğinde; \%67.9, \%74.8, \%77.0, \%78.3, \%80.3, $\% 82.0$ ve $\% 84.2$ olarak kaydedilmiştir. Ancak akşamüstü $17::^{00}-18:{ }^{00}$ saatlerinde kaydedilen KAH toparlanma oranları ise aynı sirayla; $\% 60.8, \% 68.1, \% 70.2, \% 72.2, \% 75.0, \% 76.7$ ve \%79.6 olarak gerçekleşmiş̧ir. Buradan da anlaşılacağı gibi, sabah saatlerinde yapılan yüksek şiddetli yüklenme sonrasında KAH daha fazla toparlanma eğilimi göstermektedir. Ancak, relatif $\mathrm{VO}_{2}$ toparlanma oranları açısından günün farklı saatlerine ilişkin olarak belirginlik kazanan bir eğilim yoktur (Fig. 6). Nitekim sabah $08::^{.0}-09:{ }^{00}$ saatlerindeki relatif $\mathrm{VO}_{2}$ toparlanma oranlar1 sirasıyla ele alındığında; \%32.2, \%75.1, \%85.9, \%89.5, \%91.0, \%91.7, \%93.2 ve \%93.9 olarak ve akşamüstü $17:^{00}-18:^{00}$ saatlerinde ise aynı sırayla; \%33.3, \%76.1, \%85.0, \%88.5, \%89.7, $\% 91.9, \% 93.6$ ve \%94.1 olarak gerçekleşmiştir. KAH toparlanma oranlarında sabah saatleri lehine gözlenen toparlanma eğilimi ile birlikte (Fig. 5), vücut sıcaklığı toparlanma değerlerinin de öğlen ve öğleden sonraki saatlere göre sabah $08::^{00}-09:{ }^{00}$ saatlerinde daha düşük ortalama değerlerle seyrettiği Fig. 7'de görülebilir. Toparlanma sürecine ilişkin olarak ortalama kan 
basınc1 değerlerinde ise diurnal değişim anlamlı değildir (Tablo 6). Literatürde toparlanma dönemindeki diurnal değişimi inceleyen az sayıdaki çalışmada (Güneş 1998; Güvenç 2004; Nicolas 2007; Waterhouse 2007; Morris 2009), genellikle KAH değişkeni üzerinden değerlendirmeler yapılmıştır (Güneş 1998; Güvenç 2004; Waterhouse 2007; Morris 2009). Diğer taraftan, vücut sıcaklığındaki toparlanmaya ilişkin olarak diurnal değişkenlikleri gösteren araştırma sonuçları da bulunmaktadır (Waterhouse 2007). Bununla birlikte, ulaşılabilen literatürde $\mathrm{VO}_{2}$ değerlerinde toparlanmaya ilişkin olarak diurnal değişkenliğin araştırıldığı herhangi bir çalışmaya rastlanmamıştır. Yapılan bir çalışmada akşamüstü saatlerinde zirve KAH değerlerinin en yüksek, KAH toparlanma hızının ise en düşük olduğu belirtilmektedir (Güneş 1998). KAH toparlanma düzeyinin sabah saatlerine göre akşamüstü saatlerinde daha düşük olduğunu gösteren başka araştırma sonuçları da mevcuttur (Güvenç 2004; Nicolas 2007). Diğer taraftan literatürde, toparlanma periyoduna ilişkin anlamlı ölçüde diurnal ya da gün içi değişkenlik gözlenmediğini gösteren araştırma bulguları da bulunmaktadır (Waterhouse 2007; Morris 2009).

Sonuç olarak, kısa süreli yüksek şiddetli yüklenme ve sonrasındaki toparlanma sürecine ilişkin diurnal değişkenliğin incelendiği bu çalışmada elde edilen tüm bulgulardan hareketle genel bir değerlendirme yapıldığında, yüklenmeyle sergilenen performans değerleri ve yüklenmeye yanıtlar bakımından öğleden önce ve sabah saatlerinde daha düşük değerler kaydedilirken, toparlanma düzeyi açısından da sabah saatleri lehinde bir eğilim söz konusudur. Başka bir deyişle, öğleden sonra akşamüstü saatlerde yüklenim performansı ve yanıtlarının daha yüksek olma eğilimi vardır, ancak toparlanma sabah saatlerine göre daha yavaş seyredebilmektedir. Diğer taraftan bu çalışmada incelenen fiziksel performans değerleri ve fizyolojik yanıtlara ilişkin olarak, birçok durumda diurnal değişkenliğin istatistiksel açıdan anlamlılık düzeyine erişmemesi, bu değişkenlerde gün içi ritim olmadığı anlamına gelmemektedir. Nitekim ele alınan bu değişkenlerdeki gün içi genlik düzeyi zaten dar bir aralıkta seyretmektedir (Atkinson \& Reilly 1996; Reilly, Atkinson \& Waterhouse 1997; Drust 2005). Bir başka deyişle, gün içerisinde oluşan salınım karakteri gereği, kaydedilen en düşük ve en yüksek değerler arasındaki farklılık küçük düzeylerde olabilmekte ve daha sık ölçüm aralıkları, daha büyük örneklem ve daha hassas ölçüm yöntemleri gerektirebilmektedir. Dolayısı ile başka araştırmalarda da olduğu gibi, bu çalışmada da gün içerinde farklı zamanlarda kaydedilen ortalama değerler bakımından da sonuçlar değerlendirilmiş ve diurnal değişkenliğe ilişkin belirgin eğilimler ortaya konulmuştur.

Buradan hareketle bu çalışmadan elde edilen sonuç şu şekilde özetlenebilir; yüksek şiddetli egzersiz performansı akşamüstü daha yüksek olma eğilimi gösterirken, toparlanma yanıtları sabah saatlerinde daha fazla olma eğilimindedir. Bunun uygulamadaki karşılığı, antrenmanlarda yüksek şiddetli yüklenmeler sabah saatlerinde planlanır ise toparlanma süreci daha hızlı gerçekleşebilir sonucunu beraberinde getirir. Ancak, fiziksel performans testleri ve performansın en üst seviyede olması gereken müsabakalar açısından akşamüstü saatler daha uygun olabilir. Bununla birlikte, gelecekte yapılacak benzer araştırmalarda, örneklem büyüklüğüne ve takip edilecek yönteme bağlı olarak bu çalışmada gözlenen eğilimler anlamlılık kazanabilir ve daha farklı yorumlar yapılabilir. Özellikle toparlanma sürecine ilişkin olarak farklı değişkenlerinde değerlendirildiği benzer çalışmaların gelecekte daha büyük araştırma grupları ve daha sık ölçüm aralıkları ile yapılması gerekmektedir. 


\section{KAYNAKÇA}

Akkurt S., Gür H. \& Küçükoğlu S. (1996). “Performans Test Sonuçlarının Diurnal Görünümü”. Spor Hekimliği Dergisi 31/3 (1996) 93-105.

Aslan A., Güvenç A., Hazır T. \& Açıkada C. (2011). "Genç Futbolcularda Yüksek Şiddette Yüklenme Sonrasında Toparlanma Dinamikleri”. Spor Bilimleri Dergisi 22/3 (2011) 93-103.

Aslan A. (2013). "Cardiovascular Responses, Perceived Exertion and Technical Actions During SmallSided Recreational Soccer: Effects of Pitch Size and Number of Players". Journal of Human Kinetics 38 (2013) 95-105.

Atkinson G. \& Reilly T. (1996). "Circadian Variation in Sports Performance". Sports Medicine 21/4 (1996) 292-312.

Atkinson G., Todd C., Reilly T. \& Waterhouse J. (2005). "Diurnal Variation in Cycling Performance: Influence of Warm-Up". Journal of Sports Sciences 23/3 (2005) 321-329.

Booth J., Marino F. \& Ward J. (1997). "Improved Running Performance in Hot Humid Conditions Following Whole Body Precooling". Medicine and Science in Sports and Exercise 29/7 (1997) 943-949.

Brisswalter J., Bieuzen F., Giacomoni M., Tricot V. \& Falgairette G. (2007). "Morning-to-Evening Differences in Oxygen Uptake Kinetics in Short-Duration Cycling Exercise". Chronobiology International 24/3 (2007) 495-506.

Callard D., Davenne D., Lagarde D., Meney I., Gentil C. \& Van Hoecke J. (2001). "Nycthemeral Variations in Core Temperature and Heart Rate: Continuous Cycling Exercise Versus Continuous Rest”. International Journal of Sports Medicine 22/8 (2001) 553-557.

Cristancho E., Riveros A., Sánchez A., Peñuela O. \& Böning D. (2016). "Diurnal Changes of Arterial Oxygen Saturation and Erythropoietin Concentration in Male and Female Highlanders". Physiological Reports 4/17 (2016) 12901.

Deschodt V. J. \& Arsac L. M. (2004). "Morning vs. Evening Maximal Cycle Power and Technical Swimming Ability". The Journal of Strength \& Conditioning Research 18/1 (2004) 149-154.

Drust B., Waterhouse J., Atkinson G., Edwards B. \& Reilly T. (2005). "Circadian Rhythms in Sports Performance-An Update". Chronobiology International 22/1 (2005) 21-44.

Ghattassi K., Hammouda O., Graja A., Boudhina N., Chtourou H., Hadhri S., ... \& Souissi N. (2016). "Morning Melatonin İngestion and Diurnal Variation of Short-Term Maximal Performances in Soccer Players". Acta Physiologica Hungarica 103/1 (2016) 94-104.

Güneş H., Arslan A. \& Erdal S. (1998). "Toplam Dinlenme Nabzının Sirkadien Ritminin Araştırılması”. Spor Bilimleri Dergisi 9/1 (1998) 15-29.

Güvenç A. \& Turgut A. (2004). "Anaerobik Test Sonrası Anaerobik Güç, Kapasite ve Kalp Atım Hızı Değerlerinde Diurnal (Gün İçi) Değişimin İncelenmesi”. Gazi Beden Eğitimi ve Spor Bilimleri Dergisi 9 (2004) 61-70.

Güvenç A., Açıkada C., Aslan A. \& Özer K. (2011). "Daily Physical Activity and Physical Fitness in 11to 15-Year-Old Trained and Untrained Turkish Boys". Journal of Sports Science and Medicine, 10 (2011) 502-514.

Hatfield D. L., Nicoll J. X. \& Kraemer W. J. (2016). "Effects of Circadian Rhythm on Power, Force, and Hormonal Response in Young Men". The Journal of Strength \& Conditioning Research 30/3 (2016) 725-732.

Hill D. W. \& Smith J. C. (1991). "Circadian Rhythm in Anaerobic Power and Capacity". Canadian Journal of Sport Sciences 16/1 (1991) 30-32.

Martin L. \& Thompson K. (2000). "Reproducibility of Diurnal Variation in Submaximal Swimming". International Journal of Sports Medicine 21/06 (2000) 387-392.

Morris C., Atkinson G., Drust B., Marrin K. \& Gregson W. (2009). "Human Core Temperature Responses During Exercise and Subsequent Recovery: An Important Interaction Between Diurnal Variation and Measurement Site". Chronobiology International 26/3 (2009) 560-575.

Nicolas A., Gauthier A., Michaut A. \& Davenne D. (2007). "Effect of Circadian Rhythm of Neuromuscular Properties on Muscle Fatigue During Concentric and Eccentric Isokinetic Actions". Isokinetics and 
Exercise Science 15/2 (2007) 117-129.

Nicolas A., Gauthier A., Trouillet J. \& Davenne D. (2008). "The Influence of Circadian Rhythm During a Sustained Submaximal Exercise and on Recovery Process". Journal of Electromyography and Kinesiology 18/2 (2008) 284-290.

Reilly T. (2009). "The Body Clock and Athletic Performance”. Biological Rhythm Research 40/1 (2009) $37-44$.

Reilly T., Atkinson G. \& Waterhouse J. M. (1997). Biological Rhythms and Exercise. USA 1997.

Rosa J. P. P., Rodrigues D. F., Silva A., Moura Simim M. A. D., Costa V. T., Noce F. \& de Mello M. T. (2016). "2016 Rio Olympic Games: Can the Schedule of Events Compromise Athletes' Performance?". Chronobiology International 33/4 (2016) 435-440.

Rossi A., Formenti D., Vitale J. A., Calogiuri G. \& Weydahl A. (2015). "The Effect of Chronotype on Psychophysiological Responses During Aerobic Self-Paced Exercises". Perceptual and Motor Skills 121/3 (2015) 840-855.

Shiotani H., Umegaki Y., Tanaka M., Kimura M. \& Ando H. (2009). "Effects of Aerobic Exercise on the Circadian Rhythm of Heart Rate and Blood Pressure". Chronobiology International 26/8 (2009) 1636-1646.

Souissi N., Driss T., Chamari K., Vandewalle H., Davenne D., Gam A. ... \& Jousselin E. (2010). "Diurnal Variation in Wingate Test Performances: Influence of Active Warm-Up". Chronobiology International 27/3 (2010) 640-652.

Souissi N., Gauthier A., Sesboüé B., Larue J. \& Davenne D. (2004). "Circadian Rhythms in Two Types of Anaerobic Cycle Leg Exercise: Force-Velocity and 30-s Wingate Tests". International Journal of Sports Medicine 25/1 (2004) 14-19.

Thun E., Bjorvatn B., Flo E., Harris A. \& Pallesen S. (2015). "Sleep, Circadian Rhythms, and Athletic Performance". Sleep Medicine Reviews 23 (2015) 1-9.

Waterhouse J., Aizawa S., Nevill A., Edwards B., Weinert D., Atkinson G. \& Reilly T. (2007). "Rectal Temperature, Distal Sweat Rate, and Forearm Blood Flow Following Mild Exercise at Two Phases of the Circadian Cycle". Chronobiology International 24/1 (2007) 63-85. 